Review

\title{
Causes, Factors, and Control Measures of Opportunistic Premise Plumbing Pathogens-A Critical Review
}

\author{
Erin Leslie ${ }^{1}$, Jason Hinds ${ }^{2}$ (1) and Faisal I. Hai ${ }^{1, *}$ \\ 1 Strategic Water Infrastructure Laboratory, School of Civil, Mining and Environmental Engineering, \\ University of Wollongong, Wollongong, NSW 2522, Australia; el718@uowmail.edu.au \\ 2 Enware Australia Pty Ltd., Caringbah, NSW 2229, Australia; Jason.Hinds@enware.com.au \\ * Correspondence: faisal@uow.edu.au
}

check for updates

Citation: Leslie, E.; Hinds, J.; Hai, F.I. Causes, Factors, and Control Measures of Opportunistic Premise Plumbing Pathogens-A Critical Review. Appl. Sci. 2021, 11, 4474. https://doi.org/10.3390/app11104474

Academic Editor: Bart Van der Bruggen

Received: 13 March 2021

Accepted: 9 May 2021

Published: 14 May 2021

Publisher's Note: MDPI stays neutral with regard to jurisdictional claims in published maps and institutional affiliations.

Copyright: (c) 2021 by the authors. Licensee MDPI, Basel, Switzerland. This article is an open access article distributed under the terms and conditions of the Creative Commons Attribution (CC BY) license (https:/ creativecommons.org/licenses/by/ $4.0 /)$
Featured Application: This critical review is highly timely and the need of the hour, given the prolonged and unwanted building closures during the COVID-19 pandemic. Extended water age in premise plumbing greatly increases the risk of opportunistic premise plumbing pathogens.

\begin{abstract}
This review critically analyses the chemical and physical parameters that influence the occurrence of opportunistic pathogens in the drinking water distribution system, specifically in premise plumbing. A comprehensive literature review reveals significant impacts of water age, disinfectant residual (type and concentration), temperature, $\mathrm{pH}$, and pipe materials. Evidence suggests that there is substantial interplay between these parameters; however, the dynamics of such relationships is yet to be elucidated. There is a correlation between premise plumbing system characteristics, including those featuring water and energy conservation measures, and increased water quality issues and public health concerns. Other interconnected issues exacerbated by high water age, such as disinfectant decay and reduced corrosion control efficiency, deserve closer attention. Some common features and trends in the occurrence of opportunistic pathogens have been identified through a thorough analysis of the available literature. It is proposed that the efforts to reduce or eliminate their incidence might best focus on these common features.
\end{abstract}

Keywords: opportunistic premise plumbing pathogens; legionella; water age; chlorine residual; temperature

\section{Introduction}

The drinking water distribution system (DWDS) is made up of a series of components for the storage and conveyance of potable water [1,2]. These engineered systems are designed to provide an uninterrupted supply of pressurised safe drinking water to all consumers [3]. The total system can be partitioned into water main and premise plumbing systems, where the term 'premise plumbing' refers to the section of DWDS beyond public utility main and service lines [4].

The treatment and delivery of safe potable water by the mitigation of microbiological hazards has been cited as one of the ten greatest engineering achievements of the 20th century [5]. The eradication of diseases such as cholera, typhoid fever, and dysentery has been possible in developed countries through the widespread implementation of filtration and disinfection [6]. New challenges are emerging in the 21st century with regard to water quality and public safety. In 2008, the US Centers for Disease Control and Prevention (CDC) recognised that a higher frequency of waterborne disease outbreaks was caused by pathogens native to the premise plumbing environment rather than traditional pathogens associated with treatment plant or supply network $[7,8]$.

Conventionally, pathogen control is realised at the treatment plant since utilities have limited control beyond the property line where opportunistic premise plumbing pathogens reside and multiply. For this reason, their control is considered a logistical challenge that will require a shift in the current treatment paradigm. Furthermore, premise plumbing 
systems involve many components (e.g., water heaters, showers, filters, pipe and fixture materials, and HVAC systems) that have previously failed to demand attention for their role in amplification and dissemination of opportunistic pathogens [6]. Existing literature shows end-of-the line plumbing fixtures to be a significant source of microbial pathogens. The propensity for these to be sources of infection to the end user has also been established, highlighting the health impacts of plumbing fixtures that harbour pathogens. The National Research Council (NRC) has identified factors influencing the growth of opportunistic pathogens in premise plumbing as high priority for research [5]. Establishing sound scientific knowledge is important to formulate advice for utilities, property owners/managers, and manufacturers of these systems and components.

Review papers published on the topic to date provide useful accounts of occurrence [9-11], monitoring [12], individual factors [13], guidelines [14], and different methods of control $[9,15-19]$ of opportunistic premise plumbing pathogens. The current review paper fills a gap in that it provides an up-to-date and systematic comprehensive review of causes, factors, and control measures of opportunistic premise plumbing pathogens in general and Legionella in particular.

\section{Characteristics of Premise Plumbing Systems and Risk of Opportunistic Pathogens}

The distinction between main and premise distribution is marked by a number of characteristics specific to each section-for example, premise plumbing has higher surface area to volume ratios, lengthier stagnation periods, more diverse plumbing materials, and lower disinfectant residuals than municipal mains [20-23]. The other major factor here is that the risk is elevated in the extremities of the system because the end-of-line fittings are the interface between the human user/consumer of the delivered water and the fact that these fittings have many different capture points that can enhance bacterial growth. There is a significant body of literature over the past several decades, which indicates how these characteristics can impact upon water quality within the distribution system.

It is important to understand the extent to which chemical and physical parameters influence the occurrence of opportunistic pathogens in the drinking water distribution system and specifically in premise plumbing. Although opportunistic pathogens tend to occur in buildings, beyond the property line and out of utility control, the quality of water delivered up until that point can be influential for their growth. The impacts of water age, disinfectant residues (type and concentration), temperature, $\mathrm{pH}$, and pipe materials are all important-and there is very likely substantial interplay between these parameters [1,13,24-27]. Emphasis should be placed on extreme conditions (for example, those induced by water conservation efforts) including stagnation, distribution system materials, and disinfectant residuals. For example, with national legislative water conservation initiatives such as Water Efficiency Labelling and Standards (WELS), reducing water use is now commonplace, and water stagnation risks within premise plumbing systems therefore increase. This reinforces the importance of maintaining consistent and regular turnover of water flow throughout the premise plumbing system as well as utilising suitable materials for the manufacture of end-of-line plumbing products that can resist bacterial colonisation that may be encouraged due to stagnation and low water flow. Information about these aspects will provide utilities with greater knowledge of how their treatment trains and distribution infrastructure impact the occurrence of opportunistic pathogens and how they might best be modified for improved control.

One of the most important characteristics that can affect the growth and proliferation of opportunistic pathogens in premise plumbing systems is water age. Water age is a term that represents the average time taken for water to reach its point-of-use from its pointof-entry within a distribution system [28]. It is more precisely defined as a summation of residence time from the treatment facility to the water meter of a building (i.e., mains distribution) and residence time from the water meter to the point of use (i.e., premise plumbing distribution) [21]. Water age can be described primarily as a function of water 
demand, system design, and system operation [29]. As demand increases, the time that water is resident in a system decreases [28].

\subsection{Factors Contributing to Increased Water Age}

Increased retention time or stagnation is a common occurrence in drinking water distribution systems due to demand fluctuation and long intermissions [20]. Particularly with main distribution, capital planning often dictates that systems be designed to maintain pressures and quantities for future demand, which can cause increased water age if presentday demand is significantly less than that which is forecast [28].

Dead ends are essentially underutilised or redundant sections of piping where water tends to stagnate and sediment readily builds up. These can occur in water main and premise plumbing distribution systems yet can be avoided through proper design and operation [21]. Notwithstanding this, water age is likely to increase in main and premise plumbing distribution systems as water conservation practices are adopted at the community level $[3,30]$.

Water age is also expected to be higher in green building systems when all other variables are held constant [30]. Preliminary data indicate that water age in modern green homes averages $250 \%$ higher than in conventional residences. Table 1 illustrates a number of standard practices in green buildings that reduce demand and/or increase total system volume to yield higher water ages. Table 2 indicates the extent to which such measures can decrease demand within individual buildings.

Table 1. Examples of water and energy conservation strategies that reduce flow and increase volume in premise plumbing systems (information source [21]).

Type of Green Building

Net-zero rainwater office building

Leadership in Energy and Environmental

Design (LEED) certified healthcare suite

Net-zero energy house

\section{Observation}

On-site storage of up to 11,350 L. Demand was estimated to be $1700 \mathrm{~L}$ per month during the spring and up to $5500 \mathrm{~L}$ month during the summer. This resulted in a variable water age between 2 and 6.7 months.

Water demand was 60 times less water than equivalent conventional commercial buildings. A water age of 8 days was attributed to very low use at each tap in patient exam rooms, coupled with large diameter pipes stipulated by plumbing code.

Used 4 times less water than an equivalent house studied. At this site, water age was observed before and after installation of a solar water heater. Hot water storage and age was increased by up to 1.7 days.

Table 2. Example of reduction of water usage (i.e., increased water age) from conservation efforts in green buildings (data source $[21,30])$.

\begin{tabular}{rr}
\hline Type of Facility & Water/Energy Conservation Strategies That Can Increase Water Age \\
\hline Commercial buildings & A high number of fixtures increases system stagnation \\
\hline & Rainwater harvesting requires adequate storage to ensure adequate supply during droughts \\
\hline Decreased water use through behavioral changes results in high water age \\
\hline Efficient fixtures reduce flow up to three times increasing water age proportionally \\
\hline Solar water heaters can double hot water storage volume \\
\hline Rainwater harvesting reduces tap water used for non-potable purposes \\
\hline Distribution system water age is higher because water utilities sell less water than 10 years ago \\
\hline Efficient fixtures reduce flow up to three times, increasing water age proportionally
\end{tabular}

Using rainwater or reclaimed water concurrently decreases demand and increases the overall system volume. Since large storage volumes are necessary to endure drought, 
tanks are often sized to satisfy weeks or even months of demand. Furthermore, the quality and safety of rainwater used for potable water uses remains relatively less studied [31,32]. Many hot water system configurations require large tank sizes in open-loop systems that provide increased system volumes and water ages. Water-efficient fixtures also significantly reduce flow and therefore demand [15]. For example, an inefficient showerhead can use between 15 and $25 \mathrm{~L}$ of water per minute, while an efficient showerhead can use between 6 and $8 \mathrm{~L}$ of water per minute. As showers tend to run for more than $3 \mathrm{~min}$, there may be enough time to replenish the old water in the supply pipes leading to that shower. The situation is more critical for basins that are regulated between 4 and $6 \mathrm{~L}$ per minute but have a usage run time that is often less than $10 \mathrm{~s}$. This pulls 'slugs' of heated water into a premise system without it ever actually reaching the end of line, providing new nutrients to enhance biofilm.

\subsection{Expected Changes in Water Quality Resulting from Elevated Water Age}

Water age is a major factor in water quality deterioration within distribution systems, which occurs via reactions within the bulk water and/or interactions between plumbing materials and the water [28]. As water is conveyed through the system, it is subject to various chemical, physical, and aesthetic transformations, which will proceed to a greater or lesser extent according to factors such as water flow rate, finished water quality, plumbing materials, and deposited materials.

Evidence strongly indicates the potential for high water age to negatively impact the quality of drinking water in main and premise plumbing distribution systems. It is associated with problems including disinfectant stability, corrosion of plumbing components, scaling, development of tastes and odours, and microbial (re)growth [19,25,30,33,34]. Symptoms of high water age are often diagnosed via consumer complaints. Monitoring of various chemical and biological water quality parameters might also reveal high water age, for example, lower than expected disinfectant residuals, elevated levels of disinfectant by-products, and elevated bacterial counts [28].

Water quality concerns that can be caused or worsened by increased detention time in distribution systems, with implications on public health, are summarised in Table 3 below.

Table 3. Chemical, biological, and physical water quality issues worsened by high water age.

\begin{tabular}{ccc}
\hline Chemical Issues & Biological Issues & Physical Issues \\
\hline $\begin{array}{c}\text { Disinfection decay and } \\
\text { by-product formation }\end{array}$ & Microbial proliferation & $\begin{array}{c}\text { Temperature fluctuations; } \\
\text { taste and odour }\end{array}$ \\
\hline $\begin{array}{c}\text { Corrosion of fixtures and leaching } \\
\text { of metals from fixtures }\end{array}$ & & \\
\hline
\end{tabular}

\subsubsection{Loss of Disinfectant Residual and Microbial Ramifications}

Disinfectant decay is more likely to occur in premise plumbing systems than in main distribution due to higher pipe surface area-to-water volume ratios, more frequent stagnation points, longer detention times, higher temperatures, and lower disinfectant residuals [35-37].

Traditionally, the control of pathogens by water utilities has been achieved by coagulation, filtration, and disinfection at the point of treatment prior to distribution [21]. Free chlorine and monochloramine are the two main disinfectants preferred by utilities [38]. Mounting evidence suggests that this is no longer a sufficient approach, especially for systems challenged by high water ages, including green building designs.

The purpose of a secondary disinfectant residual in water supplied by utilities is to protect the consumer against pathogens and bacterial regrowth $[3,21]$. The selected disinfectant must ultimately inactivate microorganisms in bulk water, control or remove biofilm, and inactivate microorganisms associated with that biofilm [39]. Unlike free 
chlorine and monochloramine, ozone and ultraviolet light are not effective as residual and, therefore, they are effective only at the point of use [3,16,28,40-43].

Rhoads and Edwards [21] discuss how residuals can disappear as a result of abiotic and biotic reactions within the bulk water and/or between plumbing surfaces and the water. Factors that affect the persistence of disinfectant residuals include water quality, plumbing materials (including adhering biofilms), and system operation. In their survey of green building water systems, Rhoads et al. [30] found that chlorine and chloramine residuals were often completely absent in the green building systems, decaying up to 144 times faster in premise plumbing with high water age when compared to distribution system water.

Water quality decreases with increasing distance from the point of treatment as disinfectants decay and residual concentrations fall below adequate levels. This inevitably results in a shift towards rapid bacterial growth $[3,36,44]$. The efficacy of various disinfection methods applied for the control of opportunistic premise plumbing pathogens is detailed in Section 4, which includes a discussion of the role of in building disinfection systems.

\subsubsection{Formation of Disinfectant By-Products}

Organic and inorganic disinfection by-products (DBPs) form as disinfectants react with naturally occurring materials in potable water distribution systems [28]. DBP formation potential varies within and between systems and is a function of chemical and physical characteristics including $\mathrm{pH}$, temperature, type and level of organic matter, type and level of disinfectant residual, and contact time. Increased potential for DBP formation has been linked to increased water ages or contact times. Resulting changes in water quality could cause DBP reactions to proceed faster and go further. The challenge is to interrupt the cycle induced by the requirement for higher disinfectant dosages as decay occurs, thereby increasing DBP formation potential.

More than 600 DBPs have been identified in chlorinated tap water, including haloacetic acids (HAAs) and trihalomethanes (THMs) [45]. The USEPA describes how people who drink water containing HAAs and THMs in excess of maximum contaminant levels (MCLs) for a prolonged number of years have an increased risk of getting cancer, or experience problems with their liver, kidneys, or central nervous system [28]. However, the WHO recommends that "efficient disinfection must never be compromised" and "microbiological quality must always take precedence" when a choice must be made between meeting either microbiological guidelines or guidelines for disinfectants and disinfectant by-products [46] Thus, it might be concluded that waterborne pathogens pose a more serious and immediate threat to public health than DBPs.

\subsubsection{Corrosion Control Effectiveness}

Phosphates are often added to drinking water supplies to minimise the corrosion of piping materials [21,28,47]. Increased water age influences the effectiveness of such corrosion control inhibitors by the provision of poorly buffered waters, which challenges $\mathrm{pH}$ management [48,49]. Corrosion can reduce the lifetime of premise plumbing infrastructure and cause leaching of lead and copper into the water [6]. In addition, although there appears to be substantial interplay between corrosion control and disinfection, implications for microbial control are not fully understood.

Corrosion products react with some disinfectants to enhance or reduce their impact depending on the exact water chemistry and pipe materials $[21,50]$. For example, AlJasser [35] conducted a study showing that metallic pipes (cast iron and stainless steel) consumed more chlorine as they aged, which was likely due to the accumulation of corrosion products. Conversely, plastic pipes (polyvinylchloride and medium-density polyethylene) consumed less chlorine as they aged and exerted no demand after a decade of service.

'Blue water syndrome' i.e., blue staining occurs in waters with high levels of soluble and/or particulate copper. Although elevated levels of copper in water are not known to 
cause long-term health effects, it has been linked to gastrointestinal upset and exacerbation of problems associated with nitrate ingestion, especially in children [28]. Such occurrences are expected to be more frequent in certain situations with water conservation practices [21].

Copper corrosion failure (often referred to as pinhole leaks, and as non-uniform or pitting corrosion) is strongly attributed to frequent stagnation, as well as accumulation of debris during installation, and microbial activity [44,51]. Therefore, occurrence might be more frequent in green buildings associated with low flow velocities and low water use. Research by Lytle and Schock [52] determined free chlorine to be an important factor to induce pitting under certain conditions. Severe pitting corrosion can jeopardise the integrity of an entire plumbing system, for which costs of repair or replacement can be substantial.

Lead is a neurotoxin that can cause permanent, irreversible damage when consumed and is therefore a recognised threat to public health in water supply $[53,54]$. The corrosivity of the supply water is an important driver for lead into building plumbing systems [55]. System design and operation can also influence the rate of release [56]. Prolonged periods of stagnation and high-water age increase the contact time between water and lead-based plumbing components or solders, which can increase the rate of metal release [57]. Lytle and Schock [58] observed an exponential increase in lead levels with stagnation time in the first 20-24 h of exposure.

Lead pipe plumbing is not widespread in Australian homes relative to Europe and the US, where infrastructure is more dated [59]. Nowadays, the installation of lead-based piping and the use of lead-based solders is largely banned for new constructions and renovations. Despite this, the risk of lead exposure remains [60-65]. A field study by Elfland et al. [66] revealed that premise plumbing lines in green buildings with relatively low water demand had very high lead leaching from brass and bronze devices with lead coating.

\subsection{Impact of Water and Energy-Efficiency Initiatives}

As noted above, specific elements designed to achieve net zero or energy-efficient buildings have recently been subject to scrutiny for their potential to increase pathogen growth and aerosolisation. For example, multiple studies have demonstrated that metered faucets dispense higher levels of $P$. aeruginosa and L. pneumophilia than conventional faucets [67-70]. When the metered faucets are hands free, additional problems can arise due to the solenoid valve used to control the water flow. Such solenoid valves, when activated, force a soft polymer diaphragm against a sealing face to close the water supply. This soft 'rubberised' material can provide an ideal surface for colonisation as to the small volume of stagnant water beneath the diaphragm needed for it to operate. Notably, since the introduction of WELS in Australia, every tap now includes a mesh capture point on its outlet, which is suspected to be an ideal breeding ground for bacteria. The mechanisms driving these trends in outlet flow control devices in tap need to be better studied [71].

Solar water heaters and rainwater tanks require large storage volumes to meet sustainability goals, which increases holding time and microbial risk. Reducing hot water system temperatures in an attempt to conserve energy can also support conditions for pathogen growth in hot and cold-water systems [21,30,51]. Accordingly, critics of the Leadership in Energy and Environmental (LEED) rating system devised by the United States Green Building Council (USGBC) have reworked the acronym to stand for "Legionella Enabled Engineering Design". As noted earlier, Green Star and the WELS rating system are the equivalent benchmarks for water efficiency drives in Australia.

The main benchmarks for sustainability, Green Star and the WELS rating system in Australia, have been aiming for simplicity in order to maximise their reach and subsequent adoption. This simplicity, combined with the current approach to sustainability as a kind of box to tick, has led to a disconnection between the design and construction of a building and its ongoing occupancy and management. While the performance of a building is a priority across all levels of Green Star, these benchmarks have created unforeseen consequences for the well-being of building users by failing to demonstrate an understanding of the 
knock-on effects when a building is not managed correctly. The current water efficiency solutions under sustainability benchmarks, combined with a lack of information available within building management services have created environments perfect for the growth and transmission of opportunistic pathogens in premise plumbing systems.

Green design principles are pivotal to sustainable development. It would be unwise to abandon water and energy conservation efforts. Instead, researchers and stakeholders associated with the drinking water distribution system should continue to advance their understanding of potential water quality issues and public health concerns to formulate better policies, codes, standards, risk assessment and management approaches.

\section{Factors Governing Survival and Occurrence of Opportunistic Pathogens in Premise Plumbing Systems}

Evidence is emerging that both the number of opportunistic premise plumbing pathogens in drinking water and the number of individuals who are at risk of infection by these pathogens are increasing [2]. Representative opportunistic pathogens of concern in premise plumbing include Legionella pneumophila, which causes Legionnaires Disease and Pontiac Fever; Mycobacterium avium, which causes respiratory illness; and Pseudomonas aeruginosa [14,72]. Opportunistic premise plumbing pathogens do not tend to cause disease in a healthy host; however, they can be fatal to individuals with a compromised immune system such as the elderly, HIV-infected persons, or hospitalised patients [2,10,72]. Diseases caused by these pathogens does not spread person-to-person or through the direct consumption of drinking water. Rather, considerable evidence indicates that individuals become ill when exposed to airborne water droplets that have been seeded by the pathogens. Activities that can lead to aspiration include showering and hand washing.

\subsection{Legionella Pneumophila}

Legionella is part of the bacterial genus that includes several well-known pathogenic species including Legionella pneumophilia. It was first isolated as the causative agent in an outbreak of severe respiratory illness following the 1976 American Legion convention in Philadelphia, PA [73,74]. Around $16 \%$ of cases acquired from this convention resulted in fatality, and the illness henceforth became known as Legionnaires' disease [75]. At the time, it was hypothesised that the bacterium was harbored in cooling towers and air conditioning systems within proximity to the affected population. For decades, Legionella and Legionnaires' disease were strongly associated with these origins. In more recent times, with developments in detection and analytical methods, premise plumbing has become recognised as another important source [13,76]. Reported outbreaks of Legionnaires' diseases have been linked to water systems in hotels, cruise ships, industrial facilities, public buildings, and residences; however, the majority have occurred in hospitals, healthcare facilities, and nursing homes [77].

The growth and survival of Legionella in premise plumbing is not the sole requisite for disease. Rather, the organism must penetrate the deep alveolar region of the lungs within a susceptible host $[6,78]$. When airborne, virulent Legionella are inhaled into this region; they infect and replicate within alveolar macrophages to cause disease. To become airborne, Legionella must enter the bulk water and exit the system as bioaerosol. Aerosolisation is considered the primary mode of Legionella transmission [79,80]. Microscopic water droplets created at outlets can readily evaporate to yield only small infectious particles. These particles can travel great distances (up to $3 \mathrm{~km}$ under extreme circumstances), having complex dispersion patterns that are a function of many variables [76,81]. Pruden et al. [6] suggests that Legionella-parasitised protozoa and Legionella-containing protozoan vacuoles may be similarly released and disseminated. It has been shown that changes in operation of the premise system can dislodge Legionella colonised biofilms to increase the concentration of Legionella in bulk water and dispersed aerosols by association [12,82]. Aspiration and the instillation of contaminated water into the lung during respiratory tract manipulation also present possible routes for infection $[6,13]$. 
Legionella can be introduced into premise plumbing systems in relatively small numbers carried via high-quality finished water, or in relatively large numbers via contamination from non-potable sources (e.g., backflow from fixtures, poorly installed or maintained cross-connections, etc.) and from disruptions in the supply water distributions system $[6,13]$. Once introduced, premise plumbing provides conditions unique from main water distribution systems that stimulate colonisation. These conditions include high surface to volume ratios, excessive water age, water temperatures within optimal growth ranges, and inadequate or absent disinfectant residuals $[83,84]$. The role of biofilms, which develop on most surfaces in contact with non-sterile water, is considered fundamental for the chronic colonisation of premise plumbing by Legionella [85]. Biofilms containing amoebic host organisms facilitate replication of Legionella by providing protection from chemical and heat treatments [86,87].

Legionella can withstand a wide range of temperatures depending on system conditions and available nutrients. For example, Konishi et al. [88] documented survival between 20 and $50{ }^{\circ} \mathrm{C}$ in the presence of iron and L-cysteine. Yee and Wadowsky [84] observed optimal growth with low levels of nutrients, low flow, and stagnant water between 32 and $42{ }^{\circ} \mathrm{C}$. Tepid hot water systems resulting from improper operation in attempt to reduce energy consumption are particularly vulnerable to colonisation [6]. Although some studies have shown survival in temperatures of up to $70^{\circ} \mathrm{C}$, it is widely accepted that temperatures exceeding $55^{\circ} \mathrm{C}$ provide acceptable control $[89,90]$.

As is further detailed in Section 4, chemical disinfectant residuals can be applied to control Legionella in building water systems. Disinfection efficacy is a function of many variables including system conditions and the extent of Legionella colonisation. It has been observed that Legionella are comparatively less susceptible to chlorination than Escherichia Coli [17,42]. Therefore, disinfection might be expected to reduce competition for nutrients, enhancing the growth and survival of Legionella.

Legionella are facultative intracellular parasites [13]. This means that some Legionellae are not dependent upon a host for survival and are able to survive outside freely in environments that support their fastidious growth requirements. Despite this, Legionella within biofilms and amoebae hosts have proven to be more resistant to disinfection than free-floating, planktonic Legionella [86,87].

Legionella can enter the viable but nonculturable (VBNC) state in response to environmental stressors [91,92]. A VBNC organism remains able to infect a susceptible host but cannot be grown on culture media. Common distribution system disinfectants, including monochloramines, can induce Legionella into the VBNC state. Some Legionellae that cannot be cultivated on media can multiply in hosts and can be grown in species of FLA [13]. This relationship was first noted by Rowbotham [93] and has been described by Buse and Ashbolt [94] as a defining aspect of the Legionella lifecycle. To illustrate, Acanthamoeba (a genus of amoebae) are able to graze on Legionella at temperatures below $22{ }^{\circ} \mathrm{C}$ without repercussion; however, Legionella may bypass this process at higher temperatures to rapidly multiply, increase in virulence, and kill the amoebae host [95-97].

\subsection{Mycobacterium Avium}

Non-tuberculosis mycobacteria (NTM) are a group of opportunistic pathogens found in water and soil, including building water systems [2,72,98].

The most frequently isolated mycobacteria of the approximately 150 known species are displayed in Table 4. 
Table 4. Frequently isolated non-tuberculous mycobacteria (NTM) [6,15].

\begin{tabular}{cc}
\hline Slowing Growing Species & Rapidly Growing Species \\
\hline $\begin{array}{c}\text { Mycobacterium avium } \\
\text { subspecies avium } \\
\text { subspecies hominisuis } \\
\text { subspecies silvaticum } \\
\text { subspecies paratuberculosis } \\
\text { subspecies marseillense } \\
\text { subspecies ituriense }\end{array}$ & Mycobacterium abscessus \\
\hline Mycobacterium intracellulare & \\
\hline Mycobacterium kansasii & Mycobacterium chelonae \\
\hline Mycobacterium xenopi & Mycobacterium fortuitum \\
\hline Mycobacterium malmoense & \\
\hline Mycobacterium marinum & \\
\hline
\end{tabular}

Factors that influence Mycobacterium avium growth in pipes include temperature, water flow, nutrients, pipe material and condition, and residual disinfectant. A study by Schulze-Robbecke and Buchholtz [99] demonstrated the ability of Mycobacterium avium to survive at $50{ }^{\circ} \mathrm{C}$ for up to $60 \mathrm{~min}$. Similar results are widely replicated and can explain the residence particularly in domestic hot water heaters and pipes [100]. Another study by Lewis and Falkinham [101] observed the tolerance of Mycobacterium avium during periods of stagnancy, which is common in the operation of premise plumbing. This study also showed growth at $6 \%$ and $12 \%$ oxygen as well as in air (21\% oxygen). Another study by Falkinham et al. [102] revealed a correlation between concentrations of Mycobacterium avium and organic carbon concentrations.

Mycobacterium avium is relatively chlorine resistant and can survive concentrations otherwise able to destroy or inactivate indicator bacteria (e.g., Escherichia coli) [103]. Additionally, chlorine resistance is higher in water than in culture medium, and most stains appear more tolerant of chloramine than free chlorine disinfection. Although all NTM species are at least 100 times more resistant to chlorine and other disinfectants compared to Escherichia coli, not all withstand chlorine disinfection equally [19,103-106]. Pruden et al. [6] suggest that turbidity may be an important factor during the inactivation of planktonic NTM in drinking water. The mechanism by which disinfection selects for NTM in drinking water distribution (i.e., by reducing numbers of competing organisms) is well documented in several studies [102,107].

Pilot system studies have been designed to simulate and study the behaviour of NTM in the drinking water distribution system. One such study demonstrated the ability of Mycobacterium avium to form biofilms in pipe under different concentrations of organic matter and disinfectant residuals [107]. Furthermore, Mycobacterium avium is resistant to killing by amoebae and does not undergo phagocytosis but rather multiplies within these hosts [108]. There is mounting evidence that suggests this as another factor contributing to its residence in drinking water systems and premise plumbing.

Drinking water contains both rapid and slow-growing mycobacterial species. Although their rate of growth in rich laboratory media can be very low (at 1 generation per day), Mycobacterium avium complex (MAC) and NTM are generally well adapted to life in aqueous, flowing environments, owing to their physiological properties [6,102]. NTM possess a waxy, hydrophobic cell surface, which is a consequence of long-chain (C40-C80) mycolic acids [109]. Researchers often credit these cell envelopes as the basis for antibiotic and disinfectant resistance [110]. The waxy, hydrophobic surface of NTM cells has also been linked to increased surface adherence and biofilm formation [111,112]. The enrichment of NTM in biofilms is a particularly important aspect for slow-growing species in flowing systems. Hydrophobicity also makes NTM susceptible to dispersion and transport 
as aerosols $[113,114]$. Showerheads, swimming and therapeutic pools, hot tubs, and spas are all known settings for NTM exposure via aerosols $[115,116]$.

\subsection{Pseudomonas aeruginosa}

Pseudomonas aeruginosa is a naturally occurring bacterium in soil and water; however, it has also been isolated from drinking water distribution systems, antimicrobial soaps, and disinfectants [117-121]. Although rarely carried by healthy individuals, Pseudomonas aeruginosa has been recovered in up to $60 \%$ of hospitalised patients and is therefore considered an opportunistic pathogen [122]. Pseudomonas aeruginosa has been identified as the cause of hospital- and community-acquired cases of life-threatening pneumonia. Communityacquired infections, within a relatively healthy and normal population, are more likely linked with recreation water (e.g., contaminated swimming pools, hot tubs, and whirlpools) and characterised by relatively minor eye, ear, and skin conditions.

Tap water and premise plumbing have been established as a source of Pseudomonas aeruginosa disease, particularly in healthcare settings [123,124]. Pseudomonas aeruginosa strains present within tap water samples from sinks within intensive care units have been indistinguishable by molecular typing to strains identified within infected patients [125]. In addition, Pseudomonas aeruginosa has been found to colonise faucets for more than two years despite its absence from the mains supplying the sinks. Several studies have demonstrated that the pathogen is transmissible via direct contact and/or indirect contact. Direct contact may occur through bathing or the ingestion of contaminated water. Indirect contact may occur through contamination of a device or fomite, inhalation of aerosols dispersed from contaminated water sources, and aspiration of contaminated water or aerosols [13,126-128].

The minimal nutritional requirements of Pseudomonas aeruginosa enable its survival in a range of natural and artificial environments. It persists in distilled or deionised waters, as well as aquatic environments of moderate salinity and even in high nutrient environments $[129,130]$. The growth of Pseudomonas aeruginosa is dependent on system conditions including temperature, $\mathrm{pH}$, and oxygen conditions system. Although able to survive a wide range of temperatures (from 4 to $42^{\circ} \mathrm{C}$ ) common in premise plumbing, virulence decreases below $30^{\circ} \mathrm{C}$. Optimal growth in rich medium and suspended form is between 30 and $37^{\circ} \mathrm{C}$ [131]. Pseudomonas aeruginosa can grow well in microaerobic (i.e., not completely anaerobic) conditions expected in stagnant waters associated with low flows in premise plumbing. Growth also becomes significantly limited under acidic conditions.

Pseudomonas aeruginosa displays relative resistance against common disinfectants used in water treatment $[130,132]$. In hospital and care facility settings, infections have been linked to the pathogen's presence in solutions used for surface sterilisation, bronchoscopes washed with non-sterile water or disinfectant solutions, and in-dwelling catheters [133].

The persistence and growth of Pseudomonas aeruginosa in engineered distribution systems and premise plumbing is largely credited for its habitation in biofilms [134,135]. Through this mechanism, Pseudomonas aeruginosa colonise biofilm in plumbing fixtures, including faucets and showerheads, where risk of exposure to susceptible persons is high $[123,136]$. The production of extracellular polymeric substances (EPS) by Pseudomonas aeruginosa affords it additional protection from environmental stressors by aiding the colonisation of and organisation within biofilms.

\subsection{Common Features of Opportunistic Premise Plumbing Pathogens}

Premise plumbing has several unique features including high surface to volume ratios, unique and varied pipe materials, low levels of organic carbon, and periods of stagnation that select for certain opportunistic premise plumbing pathogens, which adapt for survival, growth, and persistence in such systems/environments much unlike 'classic' waterborne pathogens such as Salmonella and Escherichia coli. Based on the available literature, it appears reasonable to assume that such pathogens that are native to premise plumbing must share common characteristics [72]. The following section draws parallels between these examples, and Table 5 gives an overview of common qualities as indicated by the 
current body of research/literature. As previously stated, this knowledge will allow for implementation of the appropriate engineered controls to protect public health and the environment.

Table 5. Summary of features common to opportunistic premise plumbing pathogens.

\section{Characteristics}

Infection of human hosts-particularly the young, elderly, immunosuppressed, and immunocompromised Disinfectant/chlorine resistance

Persistence in drinking water distribution systems (i.e., mains and premise plumbing)

Slow growth and regrowth in drinking water distribution systems

Growth within amoebae (i.e., resistance to phagocytosis)

Biofilm formation

Thermal tolerance

Survival at low oxygen during periods of stagnation

Opportunistic premise plumbing pathogens (OPPPs), as opportunistic pathogens, infect individuals having one or more risk factors making them more susceptible than the general population to these bacteria [2,137]. OPPPs do not typically cause disease in a healthy host; however, they can be fatal to individuals with a compromised immune system such as the elderly, HIV-infected persons, or hospitalised patients. This will have implications for risk assessment and the management of OPPPs, particularly for hospitals and healthcare facilities.

Many of the diseases contracted by human hosts caused by OPPPs are difficult to treat due to their relative resistance to antibiotics. Mycobacterium avium has a thick, wax, and lipid-rich outer membrane that is not penetrated by most commonly used antibiotics [110]. Pseudomonas aeruginosa isolates also have unique barriers to entry [138]. Growth in biofilms and amoebae acts as additional barriers to the entry of antibiotics [139]. Based on this knowledge, it would be extremely difficult, if at all possible, to develop strategies for treating infections [2].

Secondly, all OPPPs are relatively resistant to chlorine and various other disinfectants used in water treatment. Falkinham et al. [2] collated information regarding the chlorine resistance of waterborne pathogens relative to Escherichia coli. This is presented below in Table 6. The issue is compounded, since OPPPs can not only survive exposure to residual disinfectant levels but also thrive as competitors for nutrients. This is an important consideration when considering drinking water treatment systems. Current practice apparently encourages reductions in population diversity and allows for the amplification of numbers of a smaller group of microorganisms [137].

Table 6. Chlorine resistance of opportunistic premise plumbing pathogens relative to Escherichia coli [2].

\begin{tabular}{ccc}
\hline Genus/Species & $\mathbf{C T}_{\mathbf{9 9 . 9}}{ }^{\mathbf{1}}$ & Reference \\
\hline Escherichia coli & 0.09 (reference) & {$[103]$} \\
Legionella pneumophila & $7.5(83$-fold) & {$[140]$} \\
Medium-grown & $52.5(580$-fold) & \\
Water-adapted & & {$[103,111]$} \\
Mycobacterium avium & $51(567$-fold) & \\
Medium-grown & $1.92(21$-fold $)$ & {$[132]$} \\
Water-adapted & Pseudomonas aeruginosa &
\end{tabular}

${ }^{1} \mathrm{CT}_{99.9 \%}$ represents the disinfectant concentration $(\mathrm{mg} / \mathrm{L})$ multiplied by the contact time (min) required to kill $99.9 \%$ of cells.

Future practice should be guided by a comprehensive reassessment of risks and treatment priorities-in many instances, the control and eradication of OPPPs could take precedence.

The distribution of OPPPs throughout drinking water systems is another point of difference with other waterborne microorganisms. The concentration of 'classic' pathogens 
such as Escherichia coli will fall as they move from the source due to the dilution and the absence of growth [102,141]. Conversely, OPPPs are native to drinking water distribution systems, and their numbers will increase beyond the treatment plant. To further complicate the matter, numbers of OPPPs do not correspond with numbers of Escherichia coli, faecal coliforms, or other measures of microbial water quality and can otherwise be difficult to measure.

Slow growth is considered to be an attribute that contributes to this lack of OPPP detection and its persistence in drinking water distribution systems. For example, it takes up to 14 days for the first appearance of Mycobacterium avium colonies incubated at $37^{\circ} \mathrm{C}$ [72]. This is considered as an advantage in the sense that a slow growth means a slow death. This is supported by Table 6, which shows increased chlorine resistance for cells of Legionella pneumophila and Mycobacterium avium, which are adapted to drinking water.

Additional common features include biofilm formation, resistance to killing by phagocytic amoebae, thermal tolerance, and survival under stagnancy (i.e., low levels of oxygen). Attachment to biofilms and growth within amoebae appear to provide OPPPs with increased protection against these harsh conditions. Biofilm formation also prevents microorganisms from being washed out of flowing pipe systems [142].

Some opportunistic pathogens, such as Mycobacterium avium, can withstand assimilable organic carbon concentrations as low as $50 \mu \mathrm{g} / \mathrm{L}$ [142]. The ability of Legionella to grow in low organic concentrations is believed to depend largely on its relationship with host amoebae. On the other hand, Pseudomonas aeruginosa is so good as persisting without readily available nutrients that it has been noted to grow in distilled water. It is important to acknowledge that the overall performance of these pathogens are not the same. Falkinham [2] writes that Mycobacterium avium is clearly the most resistant to chlorine and only Pseudomonas aeruginosa can grow under anaerobic conditions [143].

Overall, a review of common features and trends in the occurrence of opportunistic pathogens supports the view that they are well suited for growth in premise plumbing systems. Efforts to reduce or eliminate their incidence might best focus on these common features and on conditions within the premise plumbing environment.

\section{Evaluation of Specific Engineered Controls for Opportunistic Pathogens in Premise Plumbing Systems}

In order to reduce or eliminate the risk of disease caused by OPPPs, it is necessary to minimise their concentrations in the affected systems [144]. With this considered, the following sections evaluate the effectiveness of specific treatment methods and approaches.

\subsection{Source Water Treatment and Distribution System Maintenance}

The function of source water treatment and distribution system maintenance is limited in the context of OPPP control. Pruden et al. [6] has noted the emphasis of water treatment and distribution system operation more for control of amoebic pathogens (e.g., Naegleria fowleri and Acanthamoeba). Despite the propensity for such organisms (including Legionella, NTM, and Pseudomonas aeruginosa) to amplify and proliferate beyond the property line, US EPA standards mandate Legionella removal from water treatment plants. Although it remains imperative that water provided up until this point is of a high quality with acceptable disinfectant residual, focus might be more wisely placed on control measures downstream.

It appears that coagulation and filtration are effective in the removal of certain freeliving amoebae species, including Naegleria fowleri and Acanthamoeba [145-147]. It is not yet clear how this will impact the previously described relationships between free-living amoebae and Legionella, NTM, and Pseudomonas aeruginosa downstream. The positive outcome in terms of OPPP control would involve a reduction in numbers by the removal of host protection. On the other hand, it may lead to reduced competition for nutrients and therefore increased OPPP growth. Chlorination and other drinking water distribution system maintenance practices do also appear effective in the control of some amoebae. 


\subsection{Temperature Control}

As previously outlined, many studies have established that water temperatures between certain thresholds correlate with OPPP colonisation [148-150]. Accordingly, decontamination of premise hot water systems frequently occurs by 'thermal pasteurisation' or a 'superheat-and-flush' approach. This involves raising hot water heater temperatures to around $70{ }^{\circ} \mathrm{C}$ for a period of time usually around $24 \mathrm{~h}$ before 'flushing' at each outlet for a minimum of $5 \mathrm{~min}$. The water temperature should reach at least $60^{\circ} \mathrm{C}$ at the outlet. For this treatment method to be effective, dead-legs must be minimised or eliminated. This can be achieved during the design phase by shutting off valves in existing systems. Without first completing this step, there is a significant risk that these stagnant areas can re-seed the system following treatment [9].

There should be consideration of potential scale build-up inside the piping of older buildings. Under these conditions, scale functions as an insulator to protect the Legionella bacteria buried within from the temperatures required for killing. Additional flushing time could be the solution; however, protocols are required to manage the inadvertent risks of scalding and flooding. A minimum of eight hours is recommended to allow the entire scale layer to become heated to over $60^{\circ} \mathrm{C}$ [33].

In general, superheat-and-flush should only be implemented as a component for the short-term management of premise plumbing pathogens, since it can cause infrastructure damage, does not prevent re-seeding, and can exacerbate other water quality issue including tastes and odours. For example, several studies have observed recolonisation by Legionella within weeks to months after treatment [15,43,151]. Temmerman et al. [152] also demonstrated the ability of Legionella pneumophila to rapidly proliferate after temperatures were lowered and suggested this was a microbial response to nutrients released by newly killed biofilm. It is likely for these reasons that ASHRAE [153], WHO [154], and others recommend this type of thermal disinfection as an emergency measure only. Conversely, a study by van der Mee-Marquet et al. [68] indicated that thermal shock yielded persistent benefits (of greater than 6 months) at metered faucets initially colonised by Pseudomonas aeruginosa.

Plumbing codes and guidelines in Canada and Australia recommend maintaining hot water distribution temperatures above $60^{\circ} \mathrm{C}$. This is a strategy also favoured by the WHO to limit pathogen growth $[5,154]$. Unfortunately, this can be viewed as a contradiction to energy savings goals and scalding prevention, and it can also cause scaling issues. For these reasons, the US EPA recommends cooler temperatures in residences, which are less likely to be effective in pathogen control [4]. On the other hand, ASHRAE Standard 188 has been developed for Legionella control specifically in at risk buildings. It mandates temperatures above $60{ }^{\circ} \mathrm{C}$ at heater outlets and hot water temperatures above $51^{\circ} \mathrm{C}$ throughout the distribution system $[153,155]$.

Despite this, there is no detailed discussion of inherent conflicts with scaling or energy savings goals for premise plumbing. There is certainly a need to explicitly acknowledge that the risk of colonisation must be balanced with other risks including infrastructure damage (e.g., dissolution, corrosion, and scaling of plumbing materials) and scalding. Brazeau and Edwards [4] discusses the potential of water softening and/or anti-scaling chemicals to reduce or avoid permanently damaging the infrastructure when raising the temperatures in hot water systems above approximately $45^{\circ} \mathrm{C}$. Standard 188 further mandates temperatures below $25^{\circ} \mathrm{C}$ at all locations of cold water systems, which is again a worthy goal; however, this threshold is not always achievable and often exceeded.

In Australia, Environmental Health Standing Committee (enHealth) Guidelines for managing Legionella in health and aged care facilities recommend that premise plumbing systems maintain circulated heated water above $60^{\circ} \mathrm{C}$ while also ensuring that the cold water remains below $20^{\circ} \mathrm{C}$ [156]. Reducing the flow rate of end-of-line fixtures and associated pipeworks reduces the ability for the circulated heated water $\left(60^{\circ} \mathrm{C}\right)$ to travel to the outlet, regularly pasteurising supply lines and replenishing them with new water. For example, over $50 \%$ of all water use activations within a working hospital are between 4 
and $24 \mathrm{~s}$ where the hot water never reaches the outlet. Maintaining $60{ }^{\circ} \mathrm{C}$ heated water is important, but it is only effective if water flow reaches the outlet regularly.

Maintaining regular flow is just as critical on the cold supply side. There is evidence of legionella survival in cold water below $20^{\circ} \mathrm{C}$. Furthermore, cold water in premise plumbing water systems may follow the ambient temperature conditions of the adjacent environment, which typically resides between 22 and $26^{\circ} \mathrm{C}$ due to air conditioning systems or thermal conditions in plumbing ducts. Maintaining good regular flow helps ensure that the cold water does not increase in temperature and hence reducing colonisation conditions and bacterial risk. To combat both these potential risks, the enHealth guide lines ask for all fixtures that remain unused for 7 days be flushed. If facility managers do not monitor fixture use, they flush every tap once a week (resulting in enormous water wastage and recourse cost). If they do not flush any of the taps, it increases risk and makes them vulnerable to litigation if a health issue occurs. Thus, the effort to design a more water-efficient facility by reducing water flow may end up wasting more water than conventionally designed and operated facilities.

\subsection{Disinfection}

Secondary disinfection (chlorination) performed by utilities can assist in the control of many opportunistic premise plumbing pathogens, as well as traditional pathogens. Chloramine in particular is valued for its potential to reduce the risk of Legionnaires' disease and the occurrence of $P$. aeruginosa at a community level [37,157]. Despite this, the absence of disinfectant residuals and OPPP regrowth observed towards the end of main distribution systems is reason to question the suitability of this strategy $[36,44]$.

In-building and on-site chemical disinfection is recommended for facilities frequented by at-risk populations, such as hospitals and aged care facilities [153]. Chlorine, chloramine, and chlorine dioxide are commonly applied chemical disinfectants in such systems. Indeed, many facility owners and operators choose to install supplemental disinfection treatment systems on the basis of disease prevention for economic or insurance reasons. More often, the decision to employ additional treatment is motivated by an outbreak of disease or by the detection of OPPPs in building water samples. Particularly for small facilities, installation, operation, and maintenance can be too costly and complicated for facility owners and operators.

As mentioned in Section 2, the application of chlorine, and possibly chloramine can be detrimental to premise plumbing infrastructure, with potential to cause serious pinhole leaks in copper and stress corrosion failure of stainless steel [57]. An investigation of continuous chlorination revealed an increase in the incidence of pinhole leaks by up to 30 times [158].

The physical and chemical characteristics of the water entering the premise system will also influence the effectiveness of disinfection technologies to varying degrees [15,159]. For example, increased water temperatures have little impact on the effectiveness of copper or silver ions relative to chlorine and chlorine dioxide disinfectant residuals, which are lessened as reactions with organic materials and/or pipe surfaces proceed quicker and further. The acidity or alkalinity of finished water can also determine the effectiveness of chlorine, monochloramine, and copper ions to a greater extent than that of chlorine dioxide and silver ions. Many other physical and chemical parameters can also impact the performance of specific disinfectants for the control of opportunistic pathogens.

Another major weakness in this method results from the disturbance of biofilm populations and subsequent release of opportunistic pathogens. Furthermore, not all disinfectants are equally effective against bacteria within biofilms [44,160,161]. In addition to the protection provided by biofilms, the prolonged exposure to chlorine may select for chlorine or even drug resistance of certain OPPPs, including Mycobacterium Avium [162]. 


\subsubsection{Chlorine}

Laboratory and full-scale studies have been conducted to assess the effectiveness of chlorine against legionella across a range of physical and chemical conditions such as dose and residual levels, temperature, and $\mathrm{pH}[44,160,161]$. In general, it was found that higher doses of chlorine in the order of 2-6 mg/L were needed for continuous control. Chlorine was proven to be more effective on control at higher temperatures; however, it also decayed faster. The fact that higher temperatures cause decay of chlorine residual further reinforces the need to ensure regular replenishment of water within premise plumbing systems to ensure that the disinfectant can reach the system extremities (end-of-line fittings).

The bactericidal action of the chlorine was also found to be enhanced at lower $\mathrm{pH}$ levels. Turbidity is suspected to interfere with the disinfection process and may need to be addressed prior to disinfection. One study found that the linkage between Legionella pneumophila and protozoa including amoebae required much higher doses of chlorine for inactivation.

\subsubsection{Monochloramine}

Monochloramine $\left(\mathrm{NH}_{2} \mathrm{Cl}\right)$ has a more persistent and stable disinfectant residual than chlorine and does not cause undesirable tastes and odours to the same extent as other disinfectants [3]. The mechanism for inactivation by monochloramine differs from that of chlorine, which can be consumed in irrelevant reactions. Although it has a much lower disinfection efficiency, it is able to control bacterial regrowth and biofilm formation via its ability to penetrate the biofilm. Current practice is to use a chlorine-to-ammonia ratio between 3:1 and 5:1 to produce monochloramine [3]. Furthermore, several case studies recommended maintaining a residual in the order or $1-2 \mathrm{mg} / \mathrm{L}$ as an effective means for containing biofilm growth, minimising Legionella colonisation and preventing outbreaks. Flushing and frequent monitoring are essential to demonstrate acceptable ammonia and chlorine residual levels.

\subsubsection{Chlorine Dioxide}

Chlorine dioxide is a water-soluble gas having superior penetration in biofilms than elemental chlorine gas. Multiple studies have confirmed that its correct usage renders it effective in incapacitating certain bacterial pathogens, viruses, and protozoan pathogens, including Legionella [3]. Chlorine dioxide disinfection systems have been installed in hospitals to control Legionella and biofilm in hot and cold-water systems. Although a vast majority of laboratory and pilot-scale tests have determined chlorine dioxide to be effective against Legionella, a few studies argued that it was not suitable at high levels as would be applied in shock treatment or emergency remediation to inactivate Legionella pneumophila $[3,28]$. Systems that successfully perform their function have reported dosage rates between 0.4 and $0.7 \mathrm{mg} / \mathrm{L}$, while a residual between 0.1 and $0.5 \mathrm{mg} / \mathrm{L}$ at the tap is considered as usually sufficient to control Legionella—naturally higher residuals may be required in a system experiencing severe colonisation [163].

\subsubsection{Copper-Silver Ionisation}

Copper-silver ionisation has been used to control Legionella and other bacteria in various settings [164]. However, some researchers argue that it is most effective when concentrations can continually be monitored and adjusted, requiring special equipment and expertise. Both copper and silver have biocidal activity, which results in a synergistic effect in the lysing of bacteria and protozoa cells, and denaturing of their proteins [17,42]. Recommended effective concentrations of copper and silver range from 0.2 to $0.4 \mathrm{mg} / \mathrm{L}$ and $0.02-0.08 \mathrm{mg} / \mathrm{L}$, respectively [165], and they tend to be higher in larger systems. Other studies have shown the ability of these metals to penetrate biofilms. The overall efficiency of copper-silver ionisation is largely impacted by water $\mathrm{pH}$ and TDS. Silver will precipitate when subject to waters with high TDS concentrations and become unavailable for disinfection. Rohr et al. [166] warns of the potential for microbial resistance to silver 
over the time span of years. Evidence in support of in-building copper-silver ionisation originates predominately from field studies, with experts calling for additional data from controlled laboratory investigations. For example, Legionella outbreaks have been reported in buildings featuring copper-silver ionisation installations [15]. Application of this method has been severely restricted by authorities in the US and parts of Europe on this basis.

\subsubsection{Ozone}

The application of ozone and ultraviolet light (UV) disinfection techniques is limited to direct local application due to the absence of a residual effect unlike chlorine [17,42,43]. Ozone must be produced on site due to its short half-life. These systems are considered difficult to retrofit, technically challenging to maintain, and expensive [15]. The major benefit of ozone appears to be its consistent performance, which requires a short contact time and is not generally affected by temperature, $\mathrm{pH}$, or turbidity $[40,43]$. A batch-reactor study by Domingue et al. [40] demonstrated CT 99\% reduction of L. pneumophila within five minutes. Similarly, Muraca et al. [43] achieved a $5 \log$ (CT 99.999\%) reduction of Legionella pneumophilia with $0.5 \mathrm{mg}$ ozone/L within five hours. Thomas et al. [146] further demonstrated the ability of ozone to reduce established biofilms at a concentration of $0.5 \mathrm{mg}$ ozone/L. However, more research is required to determine the long-term effects (e.g., corrosivity) and efficacy of ozone.

\subsubsection{UV Disinfection}

UV disinfection is another treatment technology for the inactivation of pathogens and is commonly employed by utilities in Australia, the US, and Europe as a final polishing step in the drinking water treatment train. UV light irradiation does not kill microorganisms; rather, it damages their DNA, thereby disrupting their ability to reproduce and preventing infectivity. Optimum disinfection is achieved at a wavelength of 254 nanometres; however, efficacy of treatment can be significantly impeded by high turbidity $[18,167,168]$. High concentrations of particulate matter and certain dissolved species inhibit the effectiveness of UV disinfection by impairing the transmission of light to the target microorganisms [154]. Some studies indicate that high water temperatures can reduce the longevity of UV reactors and equipment; however other studies insist that temperature fluctuations have little or no impact on disinfection efficacy. UV disinfection does not support the formation of DBPs at doses applied to drinking water, nor does it change $\mathrm{pH}$ or treated water quality to increase corrosivity [3].

In support of UV disinfection for the control of OPPPs, it was showed that relatively low UV doses $\left(\mathrm{mJ} / \mathrm{cm}^{2}\right)$ achieved a 2-log (99\%) reduction in six different Legionella species [15]. Muraca et al. [43] showed that higher UV doses achieved a 5-log (99.999\%) reduction in $20 \mathrm{~min}$ in a recirculating model premise plumbing under various test conditions. At a higher UV dose again $\left(90 \mathrm{~mJ} / \mathrm{cm}^{2}\right)$, Miyamoto et al. [169] showed that Legionella species were inactivated within three minutes of exposure. In general, UV light is most effective on protozoa followed by bacteria and least effective against viruses. In regard to the relationship between OPPPs and free-living amoebae, Cervero-Aragó et al. [170] determined that higher fluence was required for a 4-log $(99.99 \%)$ reduction in Legionella species when co-cultured with amoeba. UV disinfection has been successfully applied to control Legionella in building water systems [167,171].

Commercial in-building UV systems are available across a wide price range and can treat between 3.7 and $1900 \mathrm{~L} / \mathrm{min}$ with minimum set-up requirements (i.e., basic plumbing skills and an electrical outlet) [168]. The most significant ongoing maintenance costs and efforts typically include the annual replacement of UV bulbs and the quarterly cleaning of the quartz sleeve through which the water flows. Due to the lack of residual provided by $\mathrm{UV}$, downstream growth of microorganisms is a concern with this method. In addition, the application of UV may diminish disinfectant residual [3]. As a result, it is often used to supplement other treatment options and/or as near as possible to the POU. UV treatment is not always possible where systems are susceptible to downstream contamination [15]. 


\subsection{In-Building Filtration}

Point-of-use (POU) devices are installed to provide treated water where needed. They are typically attached to faucets and shower heads or under the counter of a kitchen or bathroom sink. Microfiltration, ultrafiltration, nanofiltration, and reverse osmosis process are all membrane filtration technologies capable of removing contaminants. According to Springston et al. [9], these systems need to be vacuum or pressure driven. Pseudomonas aeruginosa measures 0.5 to 0.8 micrometres by 1.5 to 3.0 micrometres, and the average free-living Legionella cell is approximately 1.0 to 3.0 micrometres by 0.5 to 1.0 micrometres [172].

The pore size on microfiltration ranges from 0.1 to 0.5 micrometres and would likely be suitable for the removal of most bacteria. As the one with the largest pore size among the four main membrane types mentioned above, it can be operated under relatively low pressure and therefore low energy, so it is the cheapest [173]. Finer pore size should lead to higher removal efficiency; however, maintenance requirements and associated costs will also increase. For these reasons, hospital operators, building owners, hotels, and nursing home owners tend to use POU filtration devices as a proactive measure or in response to emergency situations rather than as a single measure.

A hospital study by Sheffer et al. [174] demonstrated the ability of POU filters at faucets to achieve greater than $99 \%$ reduction in concentration of Legionella pneumophilia and Mycobacterium isolates compared to control faucets through seven days of use. Based on this positive performance, the authors recommend that studies of a prolonged duration be conducted to systematically and scientifically evaluate efficacy on a large scale. Although POU filtration may be an effective option to limit the exposure of pathogens to high-risk patients, application is constrained due to their short maximum lifetime and membrane clogging. These sentiments are reflected by several other studies [9].

Pruden et al. [6] described the potential impacts of three common types of filters (whole building granular activated carbon (GAC), end of faucet, and end of showerhead filters) beyond simply their intended capacity to physically remove OPPPs from flow. These filters can potentially concentrate biofilms and nutrients, thereby increasing the likelihood of regrowth within the filter. Particularly with end of faucet and showerhead filters, there is the risk that biofilm shearing will increases the potential exposure to contaminated aerosols. Several studies have linked POU filters to the increased occurrence of OPPPs, particularly Pseudomonas aeruginosa $[15,123,136]$. GAC filters demonstrate a tendency to deplete disinfectant residuals and therefore increase the possibility of downstream seeding. An investigation of one building water system following an outbreak of Legionella revealed that the chloramine residual has been reduced to virtually zero due to the placement of a GAC filter at the point of entry [175]. Although this raises a new set of concerns about such treatments, this situation is generally avoided by filters applied immediately at the point of use.

\subsection{Plumbing Materials}

Extensive research has been conducted to determine the relationships between materials commonly applied in drinking water distribution systems and the occurrence of OPPPs [176]. In general, evidence supports the hypothesis that copper does not encourage growth to the extent of other materials [177]. This appears particularly true for the relationship between copper and Legionella [178]. It is proposed that this inhibiting action exerted by copper on the growth of OPPPs may not be long term. Rather, it is likely determined by the concentration of aqueous $\mathrm{Cu}^{2+}$ ions, which is a complicated function of water quality parameters, including $\mathrm{pH}$ and water age [44]. Multiple studies from Italy have correlated lower levels of Legionella colonisation with copper concentrations above $50 \mu \mathrm{g} / \mathrm{L}$ [179].

Despite its potential, copper presents a number of dichotomies that must be considered prior to its selection as part of a holistic management strategy for the control of OPPPs [13]. For example, Nguyen et al. [36] describes the mechanism of copper-accelerated decay of chlorine and chloramine disinfectant. Others have observed the role of copper as a 
trace micronutrient for certain bacteria or the adaption of certain bacteria to higher copper concentrations $[41,52,83]$.

Conclusions drawn from studies focused on the influence of plastic materials mainly advance the hypothesis that pathogen growth is supported, even encouraged in the case of Legionella and Pseudomonas aeruginosa, due to the release of organics from these materials $[13,135]$. Again, the extent of colonisation appears to be a function of water quality parameters, and under some circumstances, rubber-coated valves, ethylene propylene diene monomer (EPDM), and polyurethane surfaces can strongly encourage growth $[41,52,83]$.

\subsection{Flow Patterns and Reducing Water Age}

According to Pruden et al. [6], water flow patterns control the duration and timing of stagnation events, internal pipe velocities, presence of stagnation zones, and use of recirculation pumps. Water flow patterns in premise plumbing can influence the formation and shearing of biofilms, the transport or nutrients and disinfectants, temperature profiles throughout the system, the rate of bulk water chemical reactions including disinfectant decay, and, therefore, the occurrence of OPPPs [4]. Inherent to the number of influential factors, it is difficult to establish direct correlations between the effects of flow variations on the growth and survival of OPPPs.

Understanding how to reduce water age within a distribution network is imperative to ensuring the quality of drinking water supplied. To facilitate this, additional research is required to determine with greater certainity what range of water ages are problematic and under what circumstances. Specifically, literature directly describing the relationship between water age, and the occurrence of opportunistic premise plumbing pathogens such as legionella spp. is lacking. Exceeding this knowledge deficiency may result in a wider range of preventative and remedial actions available to lessen the effects of high water age in distribution systems. Methods currently available during design and operation include regular flushing, correct sizing, and the elimination of dead ends.

Given that water age is a function of demand, there would likely be substantial benefit in performing comprehensive modelling of occupant behaviour and consumption. This should extend to assessing the accuracy and validity of future demand prediction for the sizing of new builds. Rhoads et al. [21] recommends an increased monitoring of green buildings to identify and resolve problems as they are encountered and hence establish any trends. Then, this information might be incorporated into building codes and standards outline or circumvent any negative and unintended consequences involved.

For example, these codes and standards could mandate size requirements for plumbing system volumes according to demand-this might be validated by the knowledge that a higher premise plumbing water age will result whenever there are significant reductions to potable water demand without proportionally reducing the total system size. This approach would be most suited to the design and construction phases and would be extremely difficult, if at all possible, beyond such times. For existing pipe networks within existing structures, flushing is likely to be a more effective solution [11]. This strategy seems counterproductive to green building principals and offers the impression of water and energy wastage. Although water can be recovered for use in non-potable applications, some must be expended, especially if flushing is combined with thermal shock treatment.

\subsection{Challenges Inherent to the Current Water Treatment Paradigm}

The current water treatment doctrine originates from the need to combat waterborne pathogens such as Salmonella, Escherichia coli, and Vibrio cholerae, primarily from faecal contamination of supplies. The successful control of these disease-causing pathogens has been achieved and can be largely attributed to their natural attenuation over the time of exposure to drinking water, by treatment steps including disinfection, and because they do not multiply outside of their mammalian hosts. It has been established that in contrast, opportunistic premise plumbing pathogens are adapted to growth and persistence in drinking water, especially in building plumbing systems, and therefore tolerate disinfectant 
residuals. This explains why numbers of Legionella pneumophilia, Mycobacterium avium, and Pseudomonas aeruginosa, actually increase with distance from the treatment plant $[13,102]$.

Falkinham et al. [2] describes the three main challenges that this poses to the current paradigm for water treatment. Firstly, it is believed that source tracking within a water distribution system is of limited value, since amplification and the likelihood of detection increases in remote parts of the system. Secondly, using disinfection guidance established for the eradication of Escherichia coli can select for the prevalence of opportunistic pathogens by reducing competition for nutrients. Instead, new principals might be developed according to the susceptibility of these disinfectant-resistant opportunistic pathogens. Lastly, locations for regulatory compliance sampling tend to be at the treatment plant effluent, which is the least likely place where opportunistic premise plumbing pathogens will be detected. Unfortunately, utilities are not obligated to sample stagnant water in buildings where detection is most likely $[13,15]$.

Table 7 summarises the additional problems associated with both traditional pathogens and OPPPs. There is evidently interplay, be it synergistic or antagonistic, amongst these various problems, which complicates risk assessment and management strategies. Most notably, direct conflicts exist between the control of OPPPs and the realisation of other public safety and sustainability goals (e.g., prevention of scalding and disinfection by-products, energy conservation, water conservation, and corrosion control).

Table 7. Comparing and contrasting problems of traditional pathogens to opportunistic premise plumbing pathogens.

\begin{tabular}{|c|c|c|}
\hline & $\begin{array}{l}\text { Traditional } \\
\text { Pathogens }\end{array}$ & $\begin{array}{c}\text { Opportunistic Premise Plumbing } \\
\text { Pathogens }\end{array}$ \\
\hline Re-growth in the distribution system & Generally, no & Yes \\
\hline $\begin{array}{l}\text { Risk of disease significantly influenced by immune status } \\
\text { and/or age }\end{array}$ & No & Yes \\
\hline $\begin{array}{l}\text { Risk significantly reduced by conventional treatment (e.g., } \\
\text { source water protection, primary disinfection, filtration etc) }\end{array}$ & Yes & No \\
\hline Risk reduced by secondary disinfection and residual & Yes & No \\
\hline $\begin{array}{l}\text { Likelihood of disease increased by water use patterns, } \\
\text { plumbing hydraulics, building design and operation, } \\
\text { plumbing materials, and hot water system settings }\end{array}$ & Generally, no & Yes \\
\hline Route/mode of exposure & Ingestion & Inhalation, ingestion, skin contact \\
\hline $\begin{array}{l}\text { Water nutrient levels (organic carbon, nitrogen, phosphorus, } \\
\text { trace nutrients) influential }\end{array}$ & No & Yes \\
\hline $\begin{array}{l}\text { Conflicts between risk reduction and other goals (e.g., public } \\
\text { safety, sustainability etc.) }\end{array}$ & $\begin{array}{l}\text { Possible conflict with limiting } \\
\text { DBP formation }\end{array}$ & $\begin{array}{l}\text { Major conflict with DBP formation, } \\
\text { scalding, energy and water } \\
\text { conservation, corrosion control }\end{array}$ \\
\hline $\begin{array}{l}\text { Influence by water chemistry (temperature, } p H \text {, dissolved } \\
\text { oxygen) in main and premise distribution system }\end{array}$ & Little to none & Yes \\
\hline
\end{tabular}

Fundamentals of conventional pathogen control that are transferable to the control of OPPPs include principles of disinfection, filtration, and public education. Beyond this, there is little overlap in regard to responsible parties and solutions. Although this paper previously highlighted the common characteristics of opportunistic premise plumbing pathogens, it is not realistic that one measure will reduce numbers of all species. In fact, it might never be practical or at all possible to completely eradicate all opportunistic pathogens from premise plumbing in homes, condominiums, apartments, hospitals, and office buildings $[13,15]$. Furthermore, it is not likely that control measures will have the same outcomes in treatment plants, distribution systems, and premise plumbing as conditions within and between systems vary widely. Therefore, case-specific strategies need to be adopted. 


\section{Conclusions}

It is important to elucidate the extent to which chemical and physical parameters influence the occurrence of opportunistic pathogens in the drinking water distribution system and specifically in premise plumbing. The impacts of water age, disinfectant residual (type and concentration), temperature, $\mathrm{pH}$, and pipe materials are not well-defined, and there is very likely substantial interplay between these conditions to complicate this task. There is a link between premise plumbing system characteristics, including those featuring water and energy conservation measures, and increased water quality issues and public health concerns. Other interconnected issues exacerbated by high water age, such as disinfectant decay and reduced corrosion control efficiency, deserve unique attention. Furthermore, the relationships between these other issues and the occurrence of opportunistic pathogens must be better understood. It may not be possible to completely eliminate or manage all of these risks; hence, risk characterisation and prioritisation will be of massive importance.

Author Contributions: E.L.: Methodology, Investigation, Data curation, Formal analysis, Visualisation, Writing-Original draft; J.H.: Formal analysis, Writing-Review and editing; F.I.H.: Conceptualisation, Supervision, Methodology; Data curation, Formal analysis, Project administration, Funding acquisition, Writing - Review and editing. All authors have read and agreed to the published version of the manuscript.

Funding: This work was co-funded by the Faculty of Engineering and Information Sciences at the University of Wollongong, Australia and Enware Australia Pty Ltd.

Acknowledgments: The authors are indebted to Professor William E. Price of University of Wollongong, Australia for his insightful comments on the manuscript.

Conflicts of Interest: E.L. and F.I.H. declare no conflict of interest. There are no direct conflicts of interest; however, Jason Hinds would like to declare that he is the R\&D Manager at Enware Australia Pty Limited, who are a manufacturer of commercial plumbing products.

\section{References}

1. Martin, R.L.; Strom, O.R.; Pruden, A.; Edwards, M.A. Interactive Effects of Copper Pipe, Stagnation, Corrosion Control, and Disinfectant Residual Influenced Reduction of Legionella pneumophila during Simulations of the Flint Water Crisis. Pathogens 2020, 9, 730. [CrossRef]

2. Falkinham, J.O.; Pruden, A.; Edwards, M. Opportunistic Premise Plumbing Pathogens: Increasingly Important Pathogens in Drinking Water. Pathogens 2015, 4, 373-386. [CrossRef] [PubMed]

3. USEPA. Drinking Water Distribution Systems. Available online: www.epa.gov/dwsixyearreview/drinking-water-distributionsystems (accessed on 5 September 2017).

4. Brazeau, R.H.; Edwards, M.A. A review of the sustainability of residential hot water infrastructure: Public health, environmental impacts, and consumer drivers. J. Green Build. 2011, 6, 77-95. [CrossRef]

5. NRC. Drinking Water Distribution Systems Assessing and Reducing Risks; National Academies Press: Washington, DC, USA, 2006.

6. Pruden, A.; Edwards, M.A.; Falkinham, J.O., III. State of the Science and Research Needs for Opportunistic Pathogens in Premise Plumbing; Water Resarch Foundation: Denver, CO, USA, 2013.

7. CDC. Legionnaires Disease Associated with Potable Water in a Hotel-Ocean City, Maryland, October 2003-February 2004. Morbidity and Mortality Weekly Report (MMWR). 2005. Available online: https://www.cdc.gov/mmwr/preview/mmwrhtml/ mm5407a1.htm (accessed on 1 May 2021).

8. CDC. Primary Amebic Meningoencephalitis-Arizona, Florida, and Texas, 2007. Morbidity and Mortality Weekly Report (MMWR), 573-577. 2008. Available online: https:/ /www.cdc.gov/mmwr/preview/mmwrhtml/mm5721a1.htm (accessed on 1 May 2021).

9. Springston, J.P.; Yocavitch, L. Existence and control of Legionella bacteria in building water systems: A review. J. Occup. Environ. Hyg. 2017, 14, 124-134. [CrossRef] [PubMed]

10. Williams, M.M.; Armbruster, C.R.; Arduino, M.J. Plumbing of hospital premises is a reservoir for opportunistically pathogenic microorganisms: A review. Biofouling 2013, 29, 147-162. [CrossRef] [PubMed]

11. Proctor, C.R.; Rhoads, W.J.; Keane, T.; Salehi, M.; Hamilton, K.; Pieper, K.J.; Cwiertny, D.M.; Prévost, M.; Whelton, A.J. Considerations for large building water quality after extended stagnation. AWWA Water Sci. 2020, 2, e1186. [CrossRef] [PubMed]

12. Wang, H.; Bédard, E.; Prévost, M.; Camper, A.K.; Hill, V.R.; Pruden, A. Methodological approaches for monitoring opportunistic pathogens in premise plumbing: A review. Water Res. 2017, 117, 68-86. [CrossRef] [PubMed] 
13. Cullom, A.C.; Martin, R.L.; Song, Y.; Williams, K.; Williams, A.; Pruden, A.; Edwards, M.A. Critical Review: Propensity of Premise Plumbing Pipe Materials to Enhance or Diminish Growth of Legionella and Other Opportunistic Pathogens. Pathogens 2020, 9 , 957. [CrossRef]

14. Parr, A.; Whitney, E.A.; Berkelman, R.L. Legionellosis on the Rise: A Review of Guidelines for Prevention in the United States. J. Public Health Manag. Pract. 2015, 21, E17-E26. [CrossRef] [PubMed]

15. Carlson, K.M.; Boczek, L.A.; Chae, S.; Ryu, H. Legionellosis and Recent Advances in Technologies for Legionella Control in Premise Plumbing Systems: A Review. Water 2020, 12, 676. [CrossRef]

16. Kim, B.R.; Anderson, J.E.; Mueller, S.A.; Gaines, W.A.; Kendall, A.M. Literature review-Efficacy of various disinfectants against Legionella in water systems. Water Res. 2002, 36, 4433-4444. [CrossRef]

17. Lin, Y.E.; Stout, J.E.; Yu, V.L. Controlling Legionella in hospital drinking water: An evidence-based review of disinfection methods. Infect. Control Hosp. Epidemiol. 2011, 32, 166-173. [CrossRef] [PubMed]

18. Muraca, P.W.; Yu, V.L.; Goetz, A. Disinfection of water distribution systems for legionella: A review of application procedures and methodologies. Infect. Control Hosp. Epidemiol. 1990, 11, 79-88. [CrossRef]

19. Singh, R.; Hamilton, K.A.; Rasheduzzaman, M.; Yang, Z.; Kar, S.; Fasnacht, A.; Masters, S.V.; Gurian, P.L. Managing Water Quality in Premise Plumbing: Subject Matter Experts' Perspectives and a Systematic Review of Guidance Documents. Water 2020, $12,347$. [CrossRef]

20. Haider, T.; Haider, M.; Wruss, W.; Sommer, R.; Kundi, M. Lead in drinking water of Vienna in comparison to other European countries and accordance with recent guidelines. Int. J. Hyg. Environ. Health 2002, 205, 399-403. [CrossRef] [PubMed]

21. Rhodas, W.J.; Edwards, M.A. Green Building Design: Water Quality Considerations; Water Resources and Environmental Sustainability: Water Research Foundation: Denver, CO, USA, 2015.

22. Zietz, B.P.; Dassel de Vergara, J.; Dunkelberg, H. Copper concentrations in tap water and possible effects on infant's healthResults of a study in Lower Saxony, Germany. Environ. Res. 2003, 92, 129-138. [CrossRef]

23. Zietz, B.P.; Laß, J.; Suchenwirth, R. Assessment and management of tap water lead contamination in Lower Saxony, Germany. Int. J. Environ. Health Res. 2007, 17, 407-418. [CrossRef]

24. Buse, H.Y.; Morris, B.J.; Gomez-Alvarez, V.; Szabo, J.G.; Hall, J.S. Legionella Diversity and Spatiotemporal Variation in the Occurrence of Opportunistic Pathogens within a Large Building Water System. Pathogens 2020, 9, 567. [CrossRef] [PubMed]

25. Nisar, M.A.; Ross, K.E.; Brown, M.H.; Bentham, R.; Whiley, H. Legionella pneumophila and Protozoan Hosts: Implications for the Control of Hospital and Potable Water Systems. Pathogens 2020, 9, 286. [CrossRef] [PubMed]

26. Pierre, D.; Baron, J.L.; Ma, X.; Sidari, F.P.; Wagener, M.M.; Stout, J.E. Water Quality as a Predictor of Legionella Positivity of Building Water Systems. Pathogens 2019, 8, 295. [CrossRef]

27. Zayed, A.R.; Pecellin, M.; Salah, A.; Alalam, H.; Butmeh, S.; Steinert, M.; Lesnik, R.; Brettar, I.; Höfle, M.G.; Bitar, D.M. Characterization of Legionella pneumophila Populations by Multilocus Variable Number of Tandem Repeats (MLVA) Genotyping from Drinking Water and Biofilm in Hospitals from Different Regions of the West Bank. Pathogens 2020, 9, 862. [CrossRef]

28. USEPA. Effects of Water Age on Distribution System Water Quality; USEPA: Washington, DC, USA, 2002.

29. Yakunin, E.; Kostyal, E.; Agmon, V.; Grotto, I.; Valinsky, L.; Moran-Gilad, J. A Snapshot of the Prevalence and Molecular Diversity of Legionella pneumophila in the Water Systems of Israeli Hotels. Pathogens 2020, 9, 414. [CrossRef] [PubMed]

30. Rhoads, W.J.; Pruden, A.; Edwards, M.A. Survey of green building water systems reveals elevated water age and water quality concerns. Environ. Sci. Water Res. Technol. 2016, 2, 164-173. [CrossRef]

31. Potocnjak, M.; Siroka, M.; Rebic, D.; Gobin, I. The survival of Legionella in rainwater. Int. J. Sanit. Eng. Res. 2012, 6, 31-36.

32. Taylor, J.A.; McLoughlin, R.; Sandford, J.; Bevan, R.; Aldred, D. Legionella species: A potential problem associated with rain water harvesting systems? Indoor Built Environ. 2020, 1420326X20911128. [CrossRef]

33. Masters, S.; Parks, J.; Atassi, A.; Edwards, M.A. Distribution system water age can create premise plumbing corrosion hotspots. Environ. Monit. Assess. 2015, 187, 559. [CrossRef] [PubMed]

34. Paniagua, A.T.; Paranjape, K.; Hu, M.; Bédard, E.; Faucher, S.P. Impact of temperature on Legionella pneumophila, its protozoan host cells, and the microbial diversity of the biofilm community of a pilot cooling tower. Sci. Total Environ. 2020, 712, 136131. [CrossRef]

35. Al-Jasser, A.O. Chlorine decay in drinking-water transmission and distribution systems: Pipe service age effect. Water Res. 2007, 41, 387-396. [CrossRef]

36. Nguyen, C.; Elfland, C.; Edwards, M. Impact of advanced water conservation features and new copper pipe on rapid chloramine decay and microbial regrowth. Water Res. 2012, 46, 611-621. [CrossRef] [PubMed]

37. Wang, H.; Masters, S.; Edwards, M.A.; Falkinham, J.O.; Pruden, A. Effect of Disinfectant, Water Age, and Pipe Materials on Bacterial and Eukaryotic Community Structure in Drinking Water Biofilm. Environ. Sci. Technol. 2014, 48, 1426-1435. [CrossRef] [PubMed]

38. Seidel, C.J.; McGuire, M.J.; Summers, R.S.; Via, S. Have utilities switched to chloramines? J. AWWA 2005, 97, 87-97. [CrossRef]

39. Huang, C.; Shen, Y.; Smith, R.L.; Dong, S.; Nguyen, T.H. Effect of disinfectant residuals on infection risks from Legionella pneumophila released by biofilms grown under simulated premise plumbing conditions. Environ. Int. 2020, $137,105561$. [CrossRef]

40. Domingue, E.L.; Tyndall, R.L.; Mayberry, W.R.; Pancorbo, O.C. Effects of three oxidizing biocides on Legionella pneumophila serogroup 1. Appl. Environ. Microbiol. 1988, 54, 741-747. [CrossRef] [PubMed] 
41. Lehtola, M.J.; Miettinen, I.T.; Lampola, T.; Hirvonen, A.; Vartiainen, T.; Martikainen, P.J. Pipeline materials modify the effectiveness of disinfectants in drinking water distribution systems. Water Res. 2005, 39, 1962-1971. [CrossRef] [PubMed]

42. Lin, Y.S.; Stout, J.E.; Yu, V.L.; Vidic, R.D. Disinfection of water distribution systems for Legionella. Semin. Respir. Infect. 1998, 13, 147-159.

43. Muraca, P.; Stout, J.E.; Yu, V.L. Comparative assessment of chlorine, heat, ozone, and UV light for killing Legionella pneumophila within a model plumbing system. Appl. Environ. Microbiol. 1987, 53, 447-453. [CrossRef]

44. Zhang, Y.; Edwards, M. Accelerated chloramine decay and microbial growth by nitrification in premise plumbing. J. AWWA 2009, 101, 51-62. [CrossRef]

45. Bond, T.; Goslan, E.H.; Parsons, S.A.; Jefferson, B. A critical review of trihalomethane and haloacetic acid formation from natural organic matter surrogates. Environ. Technol. Rev. 2012, 1, 93-113. [CrossRef]

46. WHO. Guidelines for Drinking-Water Quality, 2nd ed.; Volume 1: Recommendations. Chemical Aspects; Section 3.6.4; WHO: Geneva, Switzerland, 1993.

47. Schock, M.R.; Lytle, D.A.; Clement, J.A. Effect of $p H$, DIC, Orthophosphate and Sulfate on Drinking Water Cuprosolvency; National Risk Management Research Lab.: Cincinnati, OH, USA, 1995.

48. Edwards, M.; Jacobs, S.; Taylor, R.J. The blue water phenomenon. Am. Water Work. Assoc. J. AWWA 2000, 92, 72-82. [CrossRef]

49. Marchesi, I.; Ferranti, G.; Mansi, A.; Marcelloni, A.M.; Proietto, A.R.; Saini, N.; Borella, P.; Bargellini, A. Control of Legionella Contamination and Risk of Corrosion in Hospital Water Networks following Various Disinfection Procedures. Appl. Environ. Microbiol. 2016, 82, 2959-2965. [CrossRef] [PubMed]

50. States, S.J.; Conley, L.F.; Ceraso, M.; Stephenson, T.E.; Wolford, R.S.; Wadowsky, R.M.; McNamara, A.M.; Yee, R.B. Effects of metals on Legionella pneumophila growth in drinking water plumbing systems. Appl. Environ. Microbiol. 1985, 50, 1149-1154. [CrossRef] [PubMed]

51. Edwards, M. Assessment of Non-Uniform Corrosion in Copper Piping; Project \#3015; Water Research Foundation: Denver, CO, USA, 2008.

52. Lytle, D.A.; Schock, M.R. Pitting corrosion of copper in waters with high pH and low alkalinity. J.-Am. Water Works Assoc. 2008, 100, 115-129. [CrossRef]

53. Bellinger, D.C.; Needleman, H.L. Intellectual impairment and blood lead levels. N. Engl. J. Med. 2003, 349, 500-502. [CrossRef] [PubMed]

54. Canfield, R.L.; Henderson, C.R., Jr.; Cory-Slechta, D.A.; Cox, C.; Jusko, T.A.; Lanphear, B.P. Intellectual impairment in children with blood lead concentrations below 10 microg per deciliter. N. Engl. J. Med. 2003, 348, 1517-1526. [CrossRef]

55. Xie, Y.; Giammar, D.E. Effects of flow and water chemistry on lead release rates from pipe scales. Water Res. 2011, 45, 6525-6534. [CrossRef]

56. Switzer, J.A.; Rajasekharan, V.V.; Boonsalee, S.; Kulp, E.A.; Bohannan, E.W. Evidence that Monochloramine Disinfectant Could Lead to Elevated Pb Levels in Drinking Water. Environ. Sci. Technol. 2006, 40, 3384-3387. [CrossRef] [PubMed]

57. Sarver, E.; Edwards, M. Effects of flow, brass location, tube materials and temperature on corrosion of brass plumbing devices. Corros. Sci. 2011, 53, 1813-1824. [CrossRef]

58. Lytle, D.A.; Schock, M.R. Impact of stagnation time on metal dissolution from plumbing materials in drinking water. J. Water Supply Res. Technol.-Aqua. 2000, 49, 243-257. [CrossRef]

59. Parkinson, P. Lead in Drinking Water in Australia Hazards Associated with Lead Based Solder on Pipes. Available online: http:/ / www.lead.org.au/lanv8n1/18v1-11.html (accessed on 5 September 2017).

60. Samuels, E.R.; Méranger, J.C. Preliminary studies on the leaching of some trace metals from kitchen faucets. Water Res. 1984, 18, 75-80. [CrossRef]

61. Birden, H.H., Jr.; Calabrese, E.J.; Stoddard, A. Lead Dissolution From Soldered Joints. J.-Am. Water Work. Assoc. 1985, 77, 66-70. [CrossRef]

62. Edwards, M.; Dudi, A. Role of chlorine and chloramine in corrosion of lead-bearing plumbing materials. J.-Am. Water Work. Assoc. 2004, 96, 69-81. [CrossRef]

63. Triantafyllidou, S.; Edwards, M. Critical evaluation of the NSF 61 Section 9 test water for Lead. J.-Am. Water Work. Assoc. 2007, 99, 133-143. [CrossRef]

64. Gardels, M.C.; Sorg, T.J. A Laboratory Study of the Leaching of Lead From Water Faucets. J.-Am. Water Work. Assoc. 1989, 81, 101-113. [CrossRef]

65. Boyd, G.R.; Pierson, G.L.; Kirmeyer, G.J.; Britton, M.D.; English, R.J. Lead release from new end-use plumbing components in Seattle Public Schools. J.-Am. Water Work. Assoc. 2008, 100, 105-114. [CrossRef]

66. Elfland, C.; Scardina, P.; Edwards, M. Lead-contaminated water from brass plumbing devices in new buildings. J.-Am. Water Work. Assoc. 2010, 102, 66-76. [CrossRef]

67. Halabi, M.; Wiesholzer-Pittl, M.; Schöberl, J.; Mittermayer, H. Non-touch fittings in hospitals: A possible source of Pseudomonas aeruginosa and Legionella spp. J. Hosp. Infect. 2001, 49, 117-121. [CrossRef]

68. van der Mee-Marquet, N.; Bloc, D.; Briand, L.; Besnier, J.M.; Quentin, R. Non-touch fittings in hospitals: A procedure to eradicate Pseudomonas aeruginosa contamination. J. Hosp. Infect. 2005, 60, 235-239. [CrossRef]

69. Merrer, J.; Girou, E.; Ducellier, D.; Clavreul, N.; Cizeau, F.; Legrand, P.; Leneveu, M. Should electronic faucets be used in intensive care and hematology units? Intensive Care Med. 2005, 31, 1715-1718. [CrossRef] 
70. Yapicioglu, H.; Gokmen, T.G.; Yildizdas, D.; Koksal, F.; Ozlu, F.; Kale-Cekinmez, E.; Mert, K.; Mutlu, B.; Satar, M.; Narli, N.; et al. Pseudomonas aeruginosa infections due to electronic faucets in a neonatal intensive care unit. J. Paediatr. Child Health 2012, 48, 430-434. [CrossRef]

71. Mazzotta, M.; Girolamini, L.; Pascale, M.R.; Lizzadro, J.; Salaris, S.; Dormi, A.; Cristino, S. The Role of Sensor-Activated Faucets in Surgical Handwashing Environment as a Reservoir of Legionella. Pathogens 2020, 9, 446. [CrossRef]

72. Falkinham, J.O., 3rd. Common features of opportunistic premise plumbing pathogens. Int. J. Environ. Res. Public Health 2015, 12, 4533-4545. [CrossRef]

73. Fields, B.S.; Benson, R.F.; Besser, R.E. Legionella and Legionnaires' disease: 25 years of investigation. Clin. Microbiol. Rev. 2002, 15, 506-526. [CrossRef]

74. McDade, J.E.; Shepard, C.C.; Fraser, D.W.; Tsai, T.R.; Redus, M.A.; Dowdle, W.R. Legionnaires' disease: Isolation of a bacterium and demonstration of its role in other respiratory disease. N. Engl. J. Med. 1977, 297, 1197-1203. [CrossRef]

75. Fraser, D.W.; Tsai, T.R.; Orenstein, W.; Parkin, W.E.; Beecham, H.J.; Sharrar, R.G.; Harris, J.; Mallison, G.F.; Martin, S.M.; McDade, J.E.; et al. Legionnaires' disease: Description of an epidemic of pneumonia. N. Engl. J. Med. 1977, 297, 1189-1197. [CrossRef] [PubMed]

76. Addiss, D.G.; Davis, J.P.; LaVenture, M.; Wand, P.J.; Hutchinson, M.A.; McKinney, R.M. Community-acquired Legionnaires' disease associated with a cooling tower: Evidence for longer-distance transport of Legionella pneumophila. Am. J. Epidemiol. 1989, 130, 557-568. [CrossRef]

77. Craun, G.F.; Brunkard, J.M.; Yoder, J.S.; Roberts, V.A.; Carpenter, J.; Wade, T.; Calderon, R.L.; Roberts, J.M.; Beach, M.J.; Roy, S.L. Causes of outbreaks associated with drinking water in the United States from 1971 to 2006. Clin. Microbiol. Rev. 2010, 23, 507-528. [CrossRef] [PubMed]

78. Prussin, A.J., 2nd; Schwake, D.O.; Marr, L.C. Ten Questions Concerning the Aerosolization and Transmission of Legionella in the Built Environment. Build. Environ. 2017, 123, 684-695. [CrossRef]

79. Bollin, G.E.; Plouffe, J.F.; Para, M.F.; Hackman, B. Aerosols containing Legionella pneumophila generated by shower heads and hot-water faucets. Appl. Environ. Microbiol. 1985, 50, 1128-1131. [CrossRef] [PubMed]

80. Dennis, P.J.; Wright, A.E.; Rutter, D.A.; Death, J.E.; Jones, B.P. Legionella pneumophila in aerosols from shower baths. J. Hyg. 1984, 93, 349-353. [CrossRef]

81. Hoque, S.; Farouk, B.; Haas, C.N. Development of artificial neural network based metamodels for inactivation of anthrax spores in ventilated spaces using computational fluid dynamics. J. Air Waste Manag. Assoc. (1995) 2011, 61, 968-982. [CrossRef]

82. Mermel, L.A.; Josephson, S.L.; Giorgio, C.H.; Dempsey, J.; Parenteau, S. Association of Legionnaires' disease with construction: Contamination of potable water? Infect. Control Hosp. Epidemiol. 1995, 16, 76-81. [CrossRef]

83. Neu, L.; Hammes, F. Feeding the Building Plumbing Microbiome: The Importance of Synthetic Polymeric Materials for Biofilm Formation and Management. Water 2020, 12, 1774. [CrossRef]

84. Yee, R.B.; Wadowsky, R.M. Multiplication of Legionella pneumophila in unsterilized tap water. Appl. Environ. Microbiol. 1982, 43, 1330-1334. [CrossRef]

85. Murga, R.; Forster, T.S.; Brown, E.; Pruckler, J.M.; Fields, B.S.; Donlan, R.M. Role of biofilms in the survival of Legionella pneumophila in a model potable-water system. Microbiology 2001, 147, 3121-3126. [CrossRef]

86. Abdel-Nour, M.; Duncan, C.; Low, D.E.; Guyard, C. Biofilms: The stronghold of Legionella pneumophila. Int. J. Mol. Sci. 2013, 14, 21660-21675. [CrossRef]

87. Abu Khweek, A.; Amer, A.O. Factors Mediating Environmental Biofilm Formation by Legionella pneumophila. Front Cell Infect. Microbiol. 2018, 8, 38. [CrossRef]

88. Konishi, T.; Yamashiro, T.; Koide, M.; Nishizono, A. Influence of temperature on growth of Legionella pneumophila biofilm determined by precise temperature gradient incubator. J. Biosci. Bioeng. 2006, 101, 478-484. [CrossRef] [PubMed]

89. Sheehan, K.B.; Henson, J.M.; Ferris, M.J. Legionella Species Diversity in an Acidic Biofilm Community in Yellowstone National Park. Appl. Environ. Microbiol. 2005, 71, 507-511. [CrossRef]

90. Darelid, J.; Löfgren, S.; Malmvall, B.E. Control of nosocomial Legionnaires' disease by keeping the circulating hot water temperature above 55 degrees C: Experience from a 10-year surveillance programme in a district general hospital. J. Hosp. Infect. 2002, 50, 213-219. [CrossRef] [PubMed]

91. Alleron, L.; Merlet, N.; Lacombe, C.; Frère, J. Long-term survival of Legionella pneumophila in the viable but nonculturable state after monochloramine treatment. Curr. Microbiol. 2008, 57, 497-502. [CrossRef] [PubMed]

92. Turetgen, I. Induction of Viable but Nonculturable (VBNC) state and the effect of multiple subculturing on the survival of Legionella pneumophila strains in the presence of monochloramine. Ann. Microbiol. 2008, 58, 153-156. [CrossRef]

93. Rowbotham, T.J. Preliminary report on the pathogenicity of Legionella pneumophila for freshwater and soil amoebae. J. Clin. Pathol. 1980, 33, 1179-1183. [CrossRef] [PubMed]

94. Buse, H.Y.; Ashbolt, N.J. Differential growth of Legionella pneumophila strains within a range of amoebae at various temperatures associated with in-premise plumbing. Lett. Appl. Microbiol. 2011, 53, 217-224. [CrossRef]

95. Valcina, O.; Pūle, D.; Mališevs, A.; Trofimova, J.; Makarova, S.; Konvisers, G.; Bērziňš, A.; Krūmina, A. Co-Occurrence of Free-Living Amoeba and Legionella in Drinking Water Supply Systems. Medicina 2019, 55, 492. [CrossRef]

96. Nagington, J.; Smith, D.J. Pontiac fever and amoebae. Lancet 1980, 2, 1241. [CrossRef]

97. Rowbotham, T.J. Pontiac fever, amoebae, and legionellae. Lancet 1981, 1, 40-41. [CrossRef] 
98. Falkinham, J.O. Mycobacterium avium complex: Adherence as a way of life. AIMS Microbiol. 2018, 4, 428-438. [CrossRef]

99. Schulze-Röbbecke, R.; Buchholtz, K. Heat susceptibility of aquatic mycobacteria. Appl. Environ. Microbiol. 1992, 58, $1869-1873$. [CrossRef]

100. du Moulin, G.C.; Stottmeier, K.D.; Pelletier, P.A.; Tsang, A.Y.; Hedley-Whyte, J. Concentration of Mycobacterium avium by hospital hot water systems. JAMA 1988, 260, 1599-1601. [CrossRef]

101. Lewis, A.H.; Falkinham, J.O., 3rd. Microaerobic growth and anaerobic survival of Mycobacterium avium, Mycobacterium intracellulare and Mycobacterium scrofulaceum. Int. J. Mycobacteriol. 2015, 4, 25-30. [CrossRef]

102. Falkinham, J.O., 3rd; Norton, C.D.; LeChevallier, M.W. Factors influencing numbers of Mycobacterium avium, Mycobacterium intracellulare, and other Mycobacteria in drinking water distribution systems. Appl. Environ. Microbiol. 2001, 67, 1225-1231. [CrossRef] [PubMed]

103. Taylor, R.H.; Falkinham, J.O., 3rd; Norton, C.D.; LeChevallier, M.W. Chlorine, chloramine, chlorine dioxide, and ozone susceptibility of Mycobacterium avium. Appl. Environ. Microbiol. 2000, 66, 1702-1705. [CrossRef] [PubMed]

104. Vess, R.W.; Anderson, R.L.; Carr, J.H.; Bond, W.W.; Favero, M.S. The colonization of solid PVC surfaces and the acquisition of resistance to germicides by water micro-organisms. J. Appl. Bacteriol. 1993, 74, 215-221. [CrossRef]

105. Pelletier, P.A.; du Moulin, G.C.; Stottmeier, K.D. Mycobacteria in public water supplies: Comparative resistance to chlorine. Microbiol. Sci. 1988, 5, 147-148. [PubMed]

106. Lee, E.S.; Yoon, T.H.; Lee, M.Y.; Han, S.H.; Ka, J.O. Inactivation of environmental mycobacteria by free chlorine and UV. Water Res. 2010, 44, 1329-1334. [CrossRef]

107. Norton, C.D.; LeChevallier, M.W.; Falkinham, J.O., 3rd. Survival of Mycobacterium avium in a model distribution system. Water Res. 2004, 38, 1457-1466. [CrossRef]

108. Cirillo, J.D.; Falkow, S.; Tompkins, L.S.; Bermudez, L.E. Interaction of Mycobacterium avium with environmental amoebae enhances virulence. Infect Immun. 1997, 65, 3759-3767. [CrossRef]

109. Brennan, P.J.; Nikaido, H. The envelope of mycobacteria. Annu. Rev. Biochem. 1995, 64, 29-63. [CrossRef]

110. Rastogi, N.; Frehel, C.; Ryter, A.; Ohayon, H.; Lesourd, M.; David, H.L. Multiple drug resistance in Mycobacterium avium: Is the wall architecture responsible for exclusion of antimicrobial agents? Antimicrob. Agents Chemother. 1981, 20, 666-677. [CrossRef] [PubMed]

111. Steed, K.A.; Falkinham, J.O., 3rd. Effect of growth in biofilms on chlorine susceptibility of Mycobacterium avium and Mycobacterium intracellulare. Appl. Environ. Microbiol. 2006, 72, 4007-4011. [CrossRef]

112. van Loosdrecht, M.C.; Lyklema, J.; Norde, W.; Schraa, G.; Zehnder, A.J. The role of bacterial cell wall hydrophobicity in adhesion. Appl. Environ. Microbiol. 1987, 53, 1893-1897. [CrossRef]

113. Angenent, L.T.; Kelley, S.T.; St Amand, A.; Pace, N.R.; Hernandez, M.T. Molecular identification of potential pathogens in water and air of a hospital therapy pool. Proc. Natl. Acad. Sci. USA 2005, 102, 4860-4865. [CrossRef] [PubMed]

114. Blanchard, D.C.; Syzdek, L.D. Water-to-Air Transfer and Enrichment of Bacteria in Drops from Bursting Bubbles. Appl. Environ. Microbiol. 1982, 43, 1001-1005. [CrossRef] [PubMed]

115. Kahana, L.M.; Kay, J.M.; Yakrus, M.A.; Waserman, S. Mycobacterium avium complex infection in an immunocompetent young adult related to hot tub exposure. Chest 1997, 111, 242-245. [CrossRef] [PubMed]

116. Mangione, E.J.; Huitt, G.; Lenaway, D.; Beebe, J.; Bailey, A.; Figoski, M.; Rau, M.P.; Albrecht, K.D.; Yakrus, M.A. Nontuberculous mycobacterial disease following hot tub exposure. Emerg. Infect Dis. 2001, 7, 1039-1042. [CrossRef] [PubMed]

117. Mena, K.D.; Gerba, C.P. Risk assessment of Pseudomonas aeruginosa in water. Rev. Environ. Contam. Toxicol. 2009, 201, 71-115. [CrossRef] [PubMed]

118. Bertrand, X.; Bailly, P.; Blasco, G.; Balvay, P.; Boillot, A.; Talon, D. Large Outbreak in a Surgical Intensive Care Unit of Colonization or Infection with Pseudomonas aeruginosa that Overexpressed an Active Efflux Pump. Clin. Infect. Dis. 2000, 31, e9-e14. [CrossRef] [PubMed]

119. Fanci, R.; Bartolozzi, B.; Sergi, S.; Casalone, E.; Pecile, P.; Cecconi, D.; Mannino, R.; Donnarumma, F.; Leon, A.G.; Guidi, S.; et al. Molecular epidemiological investigation of an outbreak of Pseudomonas aeruginosa infection in an SCT unit. Bone Marrow Transplant. 2009, 43, 335-338. [CrossRef] [PubMed]

120. Lanini, S.; D’Arezzo, S.; Puro, V.; Martini, L.; Imperi, F.; Piselli, P.; Montanaro, M.; Paoletti, S.; Visca, P.; Ippolito, G. Molecular epidemiology of a Pseudomonas aeruginosa hospital outbreak driven by a contaminated disinfectant-soap dispenser. PLoS ONE 2011, 6, e17064. [CrossRef]

121. Favero, M.S.; Carson, L.A.; Bond, W.W.; Petersen, N.J. Pseudomonas aeruginosa: Growth in Distilled Water from Hospitals. J. Sci. 1971, 173, 836-838. [CrossRef]

122. Cholley, P.; Thouverez, M.; Floret, N.; Bertrand, X.; Talon, D. The role of water fittings in intensive care rooms as reservoirs for the colonization of patients with Pseudomonas aeruginosa. Intensive Care Med. 2008, 34, 1428-1433. [CrossRef]

123. Trautmann, M.; Lepper, P.M.; Haller, M. Ecology of Pseudomonas aeruginosa in the intensive care unit and the evolving role of water outlets as a reservoir of the organism. Am. J. Infect. Control 2005, 33, S41-S49. [CrossRef]

124. Trautmann, M.; Michalsky, T.; Wiedeck, H.; Radosavljevic, V.; Ruhnke, M. Tap water colonization with Pseudomonas aeruginosa in a surgical intensive care unit (ICU) and relation to Pseudomonas infections of ICU patients. Infect. Control Hosp. Epidemiol. 2001, 22, 49-52. [CrossRef] [PubMed] 
125. Reuter, S.; Sigge, A.; Wiedeck, H.; Trautmann, M. Analysis of transmission pathways of Pseudomonas aeruginosa between patients and tap water outlets. Crit. Care Med. 2002, 30, 2222-2228. [CrossRef]

126. Widmer, A.F.; Wenzel, R.P.; Trilla, A.; Bale, M.J.; Jones, R.N.; Doebbeling, B.N. Outbreak of Pseudomonas aeruginosa infections in a surgical intensive care unit: Probable transmission via hands of a health care worker. Clin. Infect. Dis. Off. Publ. Infect. Dis. Soc. Am. 1993, 16, 372-376. [CrossRef] [PubMed]

127. Hollyoak, V.; Boyd, P.; Freeman, R. Whirlpool baths in nursing homes: Use, maintenance, and contamination with Pseudomonas aeruginosa. Commun. Dis. Rep. CDR Rev. 1995, 5, R102-R104. [PubMed]

128. Bert, F.; Maubec, E.; Bruneau, B.; Berry, P.; Lambert-Zechovsky, N. Multi-resistant Pseudomonas aeruginosa outbreak associated with contaminated tap water in a neurosurgery intensive care unit. J. Hosp. Infect. 1998, 39, 53-62. [CrossRef]

129. Penna, V.T.; Martins, S.A.; Mazzola, P.G. Identification of bacteria in drinking and purified water during the monitoring of a typical water purification system. BMC Public Health 2002, 2, 13. [CrossRef]

130. Mao, G.; Song, Y.; Bartlam, M.; Wang, Y. Long-Term Effects of Residual Chlorine on Pseudomonas aeruginosa in Simulated Drinking Water Fed with Low AOC Medium. Front. Microbiol. 2018, 9. [CrossRef]

131. LaBauve, A.E.; Wargo, M.J. Growth and laboratory maintenance of Pseudomonas aeruginosa. Curr. Protoc. Microbiol. 2012, 25,6 E-1. [CrossRef]

132. Grobe, S.; Wingender, J.; Flemming, H.-C. Capability of mucoid Pseudomonas aeruginosa to survive in chlorinated water. Int. J. Hyg. Environ. Health 2001, 204, 139-142. [CrossRef] [PubMed]

133. Cuttelod, M.; Senn, L.; Terletskiy, V.; Nahimana, I.; Petignat, C.; Eggimann, P.; Bille, J.; Prod'hom, G.; Zanetti, G.; Blanc, D.S. Molecular epidemiology of Pseudomonas aeruginosa in intensive care units over a 10-year period (1998-2007). Clin. Microbiol. Infect. Off. Publ. Eur. Soc. Clin. Microbiol. Infect. Dis. 2011, 17, 57-62. [CrossRef]

134. de Beer, D.; Stoodley, P.; Roe, F.; Lewandowski, Z. Effects of biofilm structures on oxygen distribution and mass transport. Biotechnol. Bioeng. 1994, 43, 1131-1138. [CrossRef]

135. Rogers, J.; Dowsett, A.B.; Dennis, P.J.; Lee, J.V.; Keevil, C.W. Influence of Plumbing Materials on Biofilm Formation and Growth of Legionella pneumophila in Potable Water Systems. Appl. Environ. Microbiol. 1994, 60, 1842-1851. [CrossRef]

136. Chaidez, C.; Gerba, C. Comparison of the microbiologic quality of point-of-use (POU)-treated water and tap water. Int. J. Environ. Health Res. 2004, 14, 253-260. [CrossRef]

137. Ley, C.J.; Proctor, C.R.; Singh, G.; Ra, K.; Noh, Y.; Odimayomi, T.; Salehi, M.; Julien, R.; Mitchell, J.; Nejadhashemi, A.P.; et al. Drinking water microbiology in a water-efficient building: Stagnation, seasonality, and physicochemical effects on opportunistic pathogen and total bacteria proliferation. Environ. Sci. Water Res. Technol. 2020, 6, 2902-2913. [CrossRef]

138. Berube, B.J.; Rangel, S.M.; Hauser, A.R. Pseudomonas aeruginosa: Breaking down barriers. Curr. Genet. 2016, 62, 109-113. [CrossRef]

139. Salah, I.B.; Ghigo, E.; Drancourt, M. Free-living amoebae, a training field for macrophage resistance of mycobacteria. Clin. Microbiol. Infect. Off. Publ. Eur. Soc. Clin. Microbiol. Infect. Dis. 2009, 15, 894-905. [CrossRef] [PubMed]

140. Kuchta, J.M.; States, S.J.; McGlaughlin, J.E.; Overmeyer, J.H.; Wadowsky, R.M.; McNamara, A.M.; Wolford, R.S.; Yee, R.B. Enhanced chlorine resistance of tap water-adapted Legionella pneumophila as compared with agar medium-passaged strains. Appl. Environ. Microbiol. 1985, 50, 21-26. [CrossRef] [PubMed]

141. Donohue, M.J.; O'Connell, K.; Vesper, S.J.; Mistry, J.H.; King, D.; Kostich, M.; Pfaller, S. Widespread molecular detection of Legionella pneumophila Serogroup 1 in cold water taps across the United States. Environ. Sci. Technol. 2014, 48, 3145-3152. [CrossRef]

142. de Sotto, R.; Tang, R.; Bae, S. Biofilms in premise plumbing systems as a double-edged sword: Microbial community composition and functional profiling of biofilms in a tropical region. J. Water Health 2020, 18, 172-185. [CrossRef]

143. Czieborowski, M.; Hübenthal, A.; Poehlein, A.; Vogt, I.; Philipp, B. Genetic and physiological analysis of biofilm formation on different plastic surfaces by Sphingomonas sp. Strain S2M10 reveals an essential function of sphingan biosynthesis. Microbiology 2020, 166, 918-935. [CrossRef]

144. Berkelman, R.L.; Pruden, A. Prevention of Legionnaires' Disease in the 21st Century by Advancing Science and Public Health Practice. Emerg. Infect. Dis. 2017, 23, 1905-1907. [CrossRef]

145. Thomas, J.M.; Ashbolt, N.J. Do free-living amoebae in treated drinking water systems present an emerging health risk? Environ. Sci. Technol. 2011, 45, 860-869. [CrossRef] [PubMed]

146. Thomas, V.; Bouchez, T.; Nicolas, V.; Robert, S.; Loret, J.F.; Lévi, Y. Amoebae in domestic water systems: Resistance to disinfection treatments and implication in Legionella persistence. J. Appl. Microbiol. 2004, 97, 950-963. [CrossRef] [PubMed]

147. Bruno, A.; Sandionigi, A.; Bernasconi, M.; Panio, A.; Labra, M.; Casiraghi, M. Changes in the drinking water microbiome: Effects of water treatments along the flow of two drinking water treatment plants in a urbanized area, milan (Italy). Front. Microbiol. 2018, 9, 1-12. [CrossRef]

148. Rhoads, W.J.; Ji, P.; Pruden, A.; Edwards, M.A. Water heater temperature set point and water use patterns influence Legionella pneumophila and associated microorganisms at the tap. Microbiome 2015, 3, 67. [CrossRef]

149. Cervero-Aragó, S.; Schrammel, B.; Dietersdorfer, E.; Sommer, R.; Lück, C.; Walochnik, J.; Kirschner, A. Viability and infectivity of viable but nonculturable Legionella pneumophila strains induced at high temperatures. Water Res. 2019, 158, 268-279. [CrossRef]

150. Dai, D.; Rhoads, W.J.; Edwards, M.A.; Pruden, A. Shotgun Metagenomics Reveals Taxonomic and Functional Shifts in Hot water microbiome due to temperature setting and stagnation. Front. Microbiol. 2018, 9. [CrossRef] 
151. Ezzeddine, H.; Van Ossel, C.; Delmée, M.; Wauters, G. Legionella spp. in a hospital hot water system: Effect of control measures. J. Hosp. Infect. 1989, 13, 121-131. [CrossRef]

152. Temmerman, R.; Vervaeren, H.; Noseda, B.; Boon, N.; Verstraete, W. Necrotrophic growth of Legionella pneumophila. Appl. Environ. Microbiol. 2006, 72, 4323-4328. [CrossRef] [PubMed]

153. ASHRAE. ASHRAE Handbook-Heating, Ventilating, and Air-Conditioning Applications (I-P Edition); ASHRAE: Peachtree Corners, GA, USA, 2011.

154. WHO. Water Safety in Buildings; Avenue Appia: Geneva, Switzerland, 2010.

155. Rasheduzzaman, M.; Singh, R.; Haas, C.N.; Gurian, P.L. Required water temperature in hotel plumbing to control Legionella growth. Water Res. 2020, 182, 115943. [CrossRef]

156. enHealth. Guidelines for Legionella control in the Operation and Maintenance of Water Distribution Systems in Health and Aged Care Facilities; Australian Government: Canberra, Australia, 2015.

157. Potgieter, S.; Pinto, A.; Sigudu, M.; du Preez, H.; Ncube, E.; Venter, S. Long-term spatial and temporal microbial community dynamics in a large-scale drinking water distribution system with multiple disinfectant regimes. Water Res. 2018, 139, 406-419. [CrossRef]

158. Rutala, W.A.; Weber, D.J. Uses of inorganic hypochlorite (bleach) in health-care facilities. Clin. Microbiol. Rev. 1997, 10, 597-610. [CrossRef]

159. Kusnetsov, J.M.; Martikainen, P.J.; Jousimies-Somer, H.R.; Väisänen, M.-L.; Tulkki, A.I.; Ahonen, H.E.; Nevalainen, A.I. Physical, chemical and microbiological water characteristics associated with the occurrence of Legionella in cooling tower systems. Water Res. 1993, 27, 85-90. [CrossRef]

160. Wang, H.; Masters, S.; Hong, Y.; Stallings, J.; Falkinham, J.O.; Edwards, M.A.; Pruden, A. Effect of disinfectant, water age, and pipe material on occurrence and persistence of Legionella, mycobacteria, Pseudomonas aeruginosa, and two amoebas. Environ. Sci. Technol. 2012, 46, 11566-11574. [CrossRef]

161. Hai, F.; Yang, S.; Asif, M.; Sencadas, V.; Shawkat, S.; Sanderson-Smith, M.; Gorman, J.; Xu, Z.; Yamamoto, K. Carbamazepine as a Possible Anthropogenic Marker in Water: Occurrences, Toxicological Effects, Regulations and Removal by Wastewater Treatment Technologies. Water 2018, 10, 107. [CrossRef]

162. Cooper, I.R.; Hanlon, G.W. Resistance of Legionella pneumophila serotype 1 biofilms to chlorine-based disinfection. J. Hosp. Infect. 2010, 74, 152-159. [CrossRef] [PubMed]

163. Fish, K.E.; Boxall, J.B. Biofilm microbiome (re)growth dynamics in drinking water distribution systems are impacted by chlorine concentration. Front. Microbiol. 2018, 9. [CrossRef] [PubMed]

164. Shih, H.-Y.; Lin, Y.E. Efficacy of copper-silver ionization in controlling biofilm- and plankton-associated waterborne pathogens. Appl. Environ. Microbiol. 2010, 76, 2032-2035. [CrossRef]

165. Cachafeiro, S.P.; Naveira, I.M.; García, I.G. Is copper-silver ionisation safe and effective in controlling legionella? J. Hosp. Infect. 2007, 67, 209-216. [CrossRef] [PubMed]

166. Rohr, U.; Senger, M.; Selenka, F.; Turley, R.; Wilhelm, M. Four Years of Experience with Silver-Copper Ionization for Control of Legionella in a German University Hospital Hot Water Plumbing System. Clin. Infect. Dis. 1999, 29, 1507-1511. [CrossRef] [PubMed]

167. Liu, L.; Xing, X.; Hu, C.; Wang, H.; Lyu, L. Effect of sequential UV/free chlorine disinfection on opportunistic pathogens and microbial community structure in simulated drinking water distribution systems. Chemosphere 2019, 219, 971-980. [CrossRef] [PubMed]

168. Chen, P.F.; Zhang, R.J.; Huang, S.B.; Shao, J.H.; Cui, B.; Du, Z.L.; Xue, L.; Zhou, N.; Hou, B.; Lin, C. UV dose effects on the revival characteristics of microorganisms in darkness after UV disinfection: Evidence from a pilot study. Sci. Total Environ. 2020, 713. [CrossRef]

169. Miyamoto, M.; Yamaguchi, Y.; Sasatsu, M. Disinfectant effects of hot water, ultraviolet light, silver ions and chlorine on strains of Legionella and nontuberculous mycobacteria. Microbios 2000, 101, 7-13.

170. Cervero-Aragó, S.; Rodríguez-Martínez, S.; Puertas-Bennasar, A.; Araujo, R.M. Effect of Common Drinking Water Disinfectants, Chlorine and Heat, on Free Legionella and Amoebae-Associated Legionella. PLoS ONE 2015, 10, e0134726. [CrossRef]

171. Schmid, J.; Hoenes, K.; Rath, M.; Vatter, P.; Hessling, M. UV-C inactivation of Legionella rubrilucens. GMS Hyg. Infect Control 2017, 12, Doc06. [CrossRef]

172. Leoni, E.; Sanna, T.; Zanetti, F.; Dallolio, L. Controlling Legionella and Pseudomonas aeruginosa re-growth in therapeutic spas: Implementation of physical disinfection treatments, including UV/ultrafiltration, in a respiratory hydrotherapy system. J. Water Health 2015, 13 4, 996-1005. [CrossRef]

173. Learbuch, K.L.G.; Lut, M.C.; Liu, G.; Smidt, H.; van der Wielen, P. Legionella growth potential of drinking water produced by a reverse osmosis pilot plant. Water Res. 2019, 157, 55-63. [CrossRef]

174. Sheffer, P.; Stout, J.; Muder, R.; Wagener, M. Efficacy of New Point-of-Use Water Filters To Prevent Exposure to Legionella and Waterborne Bacteria. Am. J. Infect. Control 2004, 32, E87. [CrossRef]

175. Molloy, S.L.; Ives, R.; Hoyt, A.; Taylor, R.; Rose, J.B. The use of copper and silver in carbon point-of-use filters for the suppression of Legionella throughput in domestic water systems. J. Appl. Microbiol. 2008, 104, 998-1007. [CrossRef]

176. Molino, P.J.; Bentham, R.; Higgins, M.J.; Hinds, J.; Whiley, H. Public Health Risks Associated with Heavy Metal and Microbial Contamination of Drinking Water in Australia. Int. J. Environ. Res. Public Health 2019, 16, 3982. [CrossRef] [PubMed] 
177. van der Kooij, D.; Veenendaal, H.R.; Scheffer, W.J.H. Biofilm formation and multiplication of Legionella in a model warm water system with pipes of copper, stainless steel and cross-linked polyethylene. Water Res. 2005, 39, 2789-2798. [CrossRef] [PubMed]

178. Lu, J.; Buse, H.Y.; Gomez-Alvarez, V.; Struewing, I.; Santo Domingo, J.; Ashbolt, N.J. Impact of drinking water conditions and copper materials on downstream biofilm microbial communities and Legionella pneumophila colonization. J. Appl. Microbiol. 2014, 117, 905-918. [CrossRef] [PubMed]

179. Borella, P.; Montagna, M.T.; Romano-Spica, V.; Stampi, S.; Stancanelli, G.; Triassi, M.; Neglia, R.; Marchesi, I.; Fantuzzi, G.; Tatò, D.; et al. Legionella infection risk from domestic hot water. Emerg. Infect. Dis. 2004, 10, 457-464. [CrossRef] [PubMed] 